\title{
Teacher cognition in language teaching: A review of research on what language teachers think, know, believe, and do
}

\author{
Simon Borg School of Education, University of Leeds, UK
}

This paper reviews a selection of research from the field of foreign and second language teaching into what is referred to here as teacher cognition - what teachers think, know, and believe and the relationships of these mental constructs to what teachers do in the language teaching classroom. Within a framework suggested by more general mainstream educational research on teacher cognition, language teacher cognition is here discussed with reference to three main themes: (1) cognition and prior language learning experience, (2) cognition and teacher education, and (3) cognition and classroom practice. In addition, the findings of studies into two specific curricular areas in language teaching which have been examined by teacher cognition - grammar teaching and literacy are discussed. This review indicates that, while the study of teacher cognition has established itself on the research agenda in the field of language teaching and provided valuable insight into the mental lives of language teachers, a clear sense of unity is lacking in the work and there are several major issues in language teaching which have yet to be explored from the perspective of teacher cognition.

\section{Introduction}

I use the term teacher cognition here to refer to the unobservable cognitive dimension of teaching what teachers know, believe, and think. Mainstream educational research in the last 25 years has recognised the impact of teacher cognition on teachers' professional lives, and this has generated a substantial body of research. Several reviews of this work have been undertaken (Calderhead 1996; Carter 1990; Clark \& Peterson 1986; Fenstermacher 1994; Richardson 1996; Verloop, Van Driel, \& Meijer

Simon Borg is Senior Lecturer in TESOL at the School of Education, University of Leeds, UK, where he directs the $B A$ Educational Studies (TESOL) programme for Oman and co-ordinates the MA TESOL (Distance) programme. His key areas of interest are language teacher cognition, grammar teaching, teacher education and practitioner research. He is also joint co-ordinator for IATEFL's Research Special Interest Group.

e-mail:s.borg@education.leeds.ac.uk

web page: http://education.leeds.ac.uk/devt/research/ sborg.htm
2001) ${ }^{1}$ and the assumptions on which it is based are now largely uncontested: teachers are active, thinking decision-makers who make instructional choices by drawing on complex, practically-oriented, personalised, and context-sensitive networks of knowledge, thoughts, and beliefs. Key questions addressed in teacher cognition research include the following:

- what do teachers have cognitions about?

- how do these cognitions develop?

- how do they interact with teacher learning?

- how do they interact with classroom practice?

Figure 1 (Borg 1997) summarises the answers to these questions. It indicates that teachers have cognitions about all aspects of their work, and lists recurrent labels used to describe the various psychological constructs which I collectively refer to here as teacher cognition. The diagram also outlines relationships suggested by mainstream educational research among teacher cognition, teacher learning (both through schooling and professional education), and classroom practice. In brief, there is ample evidence that teachers' experiences as learners can inform cognitions about teaching and learning which continue to exert an influence on teachers throughout their career (e.g., Holt Reynolds 1992); there is also evidence to suggest that although professional preparation does shape trainees' cognitions, programmes which ignore trainee teachers' prior beliefs may be less effective at influencing these (e.g., Kettle \& Sellars 1996; Weinstein 1990); and research has also shown that teacher cognitions and practices are mutually informing, with contextual factors playing an important role in determining the extent to which teachers are able to implement instruction congruent with their cognitions (e.g., Beach 1994; Tabachnick \& Zeichner 1986).

Figure 1 represents a schematic conceptualisation of teaching within which teacher cognition plays a pivotal role in teachers' lives. It is within this framework, grounded in an analysis of mainstream educational research, that language teacher cognition

\footnotetext{
${ }^{1}$ Visit http://www.education.leeds.ac.uk/ edu-sbo/index.html for further detail on the background to teacher cognition
} research. 
Extensive experience of classrooms which defines early cognitions and shapes teachers' perceptions of initial training.
May affect existing cognitions

although especially when

unacknowledged, these may limit its impact.

4

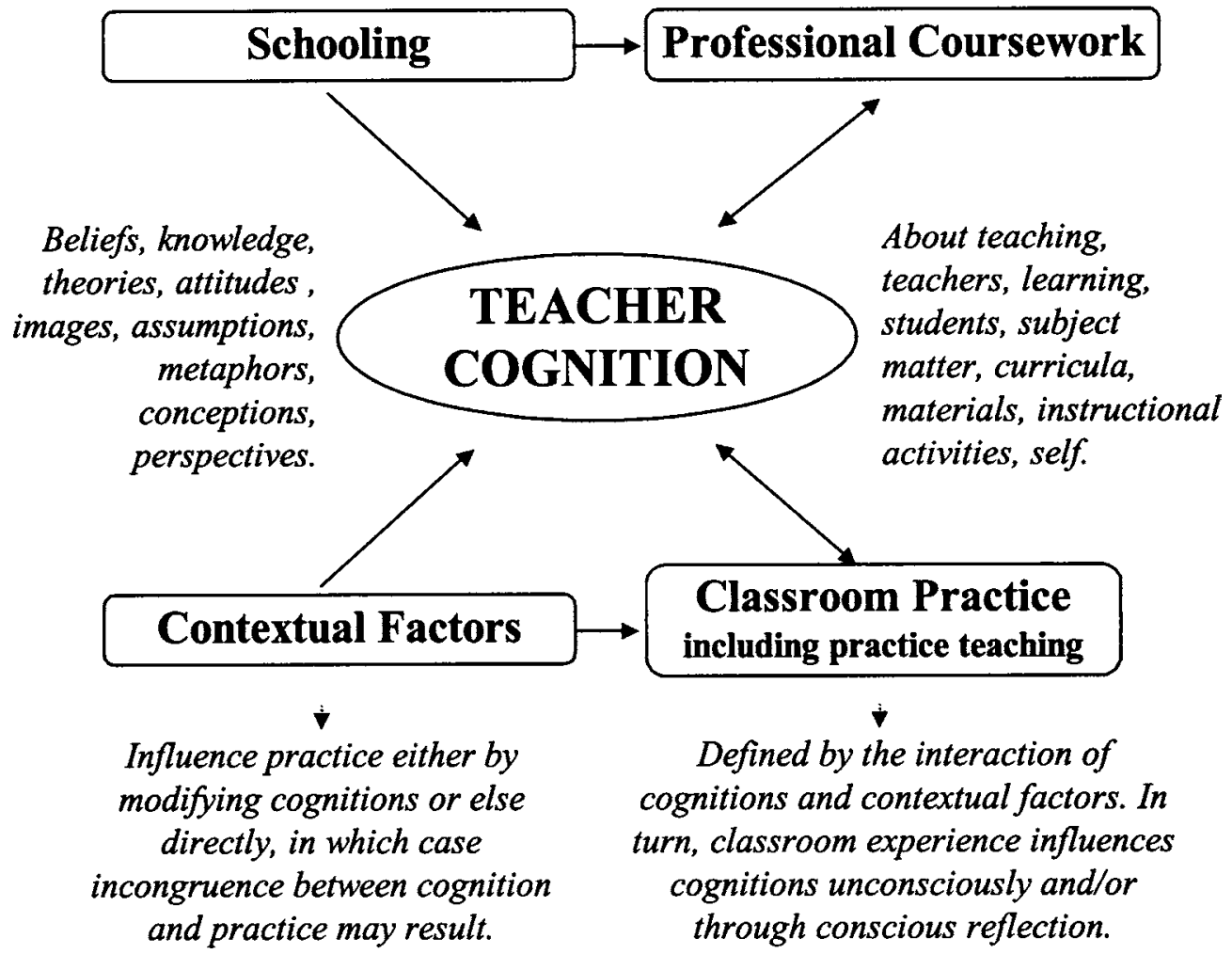

Figure 1 Teacher cognition, schooling, professional education, and classroom practice (Borg 1997)

research has emerged (see Freeman 1996; 2002), and in the review which follows I will use Figure 1 as a point of reference.

\section{Overview}

In choosing studies for this review I searched for published work examining what second or foreign language teachers, at any stage of their careers, know, believe, and think in relation to topics relevant to language teaching. I included both studies where teacher cognition is analysed in relation to classroom practice as well as those where no analysis of actual teaching is conducted. Literature searches were conducted manually and electronically ${ }^{2}$, and results narrowed down accordingly (e.g., studies of L1 teaching were discarded).

I thus identified for this review 64 studies published between 1976 and 2002, although, as Table 1 shows, 47 of these have appeared since 1996. Freeman (2002) describes 1990-2000 as the decade of consolidation (which in his analysis follows change) in research

2 The main bibliographic packages used were Ingenta, Web of Science, Science Direct, and Zetoc. on teacher knowledge and learning to teach, but his analysis is more pertinent to the mainstream educational research I referred to earlier. In the field of language teaching, the bulk of research on teacher cognition started to appear in the 1990s, picking

Table 1 Chronology of research on language teacher cognition

\begin{tabular}{lc}
\hline Year of publication & Studies in this review \\
\hline 1970 s & 1 \\
1980 s & 1 \\
1991 & 2 \\
1992 & 7 \\
1993 & 1 \\
1994 & 5 \\
1995 & 0 \\
1996 & 15 \\
1997 & 3 \\
1998 & 8 \\
1999 & 10 \\
2000 & 3 \\
2001 & 7 \\
2002 & 1 \\
Total & $\mathbf{6 4}$ \\
\hline
\end{tabular}


up a momentum in the second half of the decade which continues to gather pace today. In analysing teacher cognition in language teaching, then, 19902000 emerges as the decade of change.

\section{Topics and contexts studied}

Table 2 lists the studies included in this review and outlines the topics they focus on and the contexts in which they were conducted. This summary immediately highlights the diversity of research on language teacher cognition. In terms of topic, only two curricular areas in language teaching have been specifically examined; these are grammar (22 studies $\left.{ }^{3}\right)$ and literacy instruction (seven in total, of which five focus on reading). The remaining studies do not examine teacher cognition with respect to specific curricular areas, focusing rather on more general processes, such as knowledge growth during teacher education or planning and decision-making, and illustrating these within a language teaching context. Although it is possible to discern general recurrent themes from the list of topics in Table 2, the overriding impression is one of diversity, with hardly any replication or evidence of systematic programmes of research.

This sense of diversity becomes even more apparent when the contexts for these studies are considered. Seventeen studies have been carried out in the USA, eleven in Hong Kong, nine in the $\mathrm{UK}^{4}$, seven in Canada, and five in Australia. The remainder report studies conducted in Malta $(6)^{5}$, the Netherlands (2), Turkey (2), and Germany, Singapore, and Colombia with one each. Two studies occurred in two sites - one in the USA and Puerto Rico, and another in Hong Kong and the UK. Most of the studies have specifically examined the teaching of English, mainly in ESL as opposed to EFL contexts, though in several cases teachers of English have been just one of a larger group of foreign language teachers studied (e.g., Lam 2000; Meijer, Verloop, \& Beijaard 1999). In a few studies (e.g., Cabaroglu \& Roberts 2000; Collie Graden 1996) no teachers of English have been involved. As the process of identifying studies I outlined above suggests, the predominance of research on English language teaching in this review was not a predetermined choice; it is rather a reflection of the context in which the bulk of this work has been conducted. The omission from this review of further existing studies involving languages other than English thus merely reflects my unawareness of these rather than any desire on my part to minimise their value to the field.

\footnotetext{
${ }^{3}$ The relatively high number of studies in this group is due largely to the work of two individuals and one group of researchers who have published a number of papers.

${ }^{4} 4$ of these relate to the same larger project.

5 These all relate to one larger project.
}

Great variations in the numbers and characteristics of the teachers studied are also evident from Table 2 . The range extends from detailed case studies of individual teachers (e.g., Borg 1998c; Johnson 1996) to larger scale surveys of teachers' beliefs (Peacock 2001; Richards, Tung, \& Ng 1992). In terms of experience, again the full range is represented here, with studies of language teachers at early stages in their training, towards the end of their initial professional preparation, in their first year of teaching, and at a number of different points in their careers.

\section{Terminology in language teacher cognition research}

The study of teacher cognition is generally characterised by a multiplicity of labels which have been posited to describe, wholly or in part, the psychological context of teaching (for discussions of these see, for example, Pajares 1992; Verloop et al. 2001). While perhaps terminological innovation is a necessary process in the conceptualisation of an emerging domain of educational inquiry, this proliferation of terms has led to a 'definitional confusion' (Eisenhart, Shrum, Harding \& Cuthbert 1988). This conceptual ambiguity has been further complicated by the fact that, as Clandinin \& Connelly (1987) point out, identical terms have been defined in different ways and different terms have been used to describe similar concepts. Language teacher cognition research has inevitably been influenced by concepts established in mainstream educational literature, and consequently a range of different labels appear in the studies I review here. These are listed in Table 3.

Specific evidence of the conceptual antecedents to the work I review here can be seen in Table 3, where a number of the terms listed derive from established research traditions outside language teaching. Shulman (1987), for example, introduced the notions of pedagogical knowledge and pedagogical reasoning, while the idea of personal theories comes from Kelly's (1955) personal construct psychology. Also, the term practical knowledge is drawn from Elbaz (1981), and the notion of 'culture of teaching' comes from a research tradition reviewed in Feiman-Nemser \& Floden (1986). The conceptual history of language teacher cognition research is thus quite diverse.

The superficial diversity created by the terms in Table 3 should not mask the considerable overlap which exists among them. Collectively, they highlight the personal nature of teacher cognition, the role of experience in the development of these cognitions, and the way in which instructional practice and cognition are mutually informing. Teacher cognition also emerges here as a multidimensional concept (see Figure 1) within which, philosophical arguments apart (see, for example, Fenstermacher 1994; Orton 1996), untangling closely related 
Table 2 Topics and contexts in language teacher cognition research

Source Focus Context

Almarza (1996)

Andrews (1994)

Andrews (1997)

Andrews (1999a)

Andrews (1999b)

Bailey (1996)

Bailey (1996)

Bartels (1999)

Berry (1997)

Borg (1998b)

Borg (1998c)

Borg (1999a)

$\operatorname{Borg}(1999 \mathrm{c})$

$\operatorname{Borg}(1999 d)$

Borg (2001)

Breen et al. (2001)

Breen (1991)

Brown \&

McGannon (1998)

Brumfit et al. (1996)

Burgess \&

Etherington (2002)

Burns (1992)

Burns (1996)

Cabaroglu (2000)

Cathcart (1976)

Collie Graden (1996)
Origins, content, and change in student teachers' knowledge during teacher education, and its impact on classroom practice

Grammatical knowledge of trainees

Teachers' metalinguistic awareness and its role prospective in teachers' ability to explain a grammar point

Teachers' knowledge of grammar and grammatical terminology

Teachers' metalinguistic awareness and its impact on the linguistic input made available to learners

The influence of learning experience on teaching philosophies and practices

Experienced teachers' decisions to depart from their lesson plans

The linguistic knowledge and skills teachers draw on to realise their lesson plans in class

Teachers' awareness of learners' metalinguistic knowledge

Talk about grammar in the FL classroom

Understanding classroom practice in teaching grammar

Teacher cognition in L2 grammar teaching

Teachers' personal theories in teaching grammar

Use of grammatical terminology in classrooms

Teachers' self-perceptions of their knowledge of grammar

Relationships between principles and practices of individuals and of a group of teachers

The implicit theories of experienced language teachers

Change during teacher education in the beliefs of trainee teachers about language learning and the roles of teachers

Teachers' theories of language development and about the place of KAL in language education

Teachers' beliefs about grammar and grammar teaching

The influence of teacher beliefs on teaching writing

Teachers' theories and practices in the beginning adult L2 classroom

Change in teachers' beliefs during a 1-year postgraduate course

Teachers' and students' preferences for correction of oral errors

Beliefs and practices in foreign language reading instruction.
4 foreign language teachers on a PGCE at a British university

$82 \mathrm{EFL}$ teacher trainers working on different EFL certificate courses

5 practising English teachers and 9 teachers on a BEd in Hong Kong

20 practising and prospective ESL teachers in Hong Kong, 20 native English speaker undergraduates studying modern language and English Studies in the UK

17 secondary school teachers of English in Hong Kong, 3 of which are reported on

7 teachers on an MA course in USA

6 experienced teachers working in an intensive ESL programme in an American institute

3 experienced EFL teachers in Germany

$3721^{\text {st }}$ year undergraduates students in Hong Kong; 10 teachers of these students

2 EFL teachers in private language schools in Malta

One experienced EFL teacher in a private language school in Malta

5 EFL teachers in private language schools in Malta

2 EFL teachers in private language schools in Malta

4 EFL teachers in private language schools in Malta

2 EFL teachers in private language schools in Malta

18 experienced ESL teachers in Australia

106 language teachers enrolled on an MA in a British university

35 trainees teachers of LOTE and ESL on a Graduate Diploma in Education at an Australian university

Teachers of English, French, Spanish, and German in 3 state secondary schools in the UK

48 teachers of English for Academic Purposes in UK universities

6 teachers in beginning ESL classes in Australia

6 experienced ESL teachers of beginning adult learners in Australia

20 students on a PGCE Secondary in Modern Languages at a British university 188 students in ESL classes in the USA 59 ESL teachers

6 secondary teachers of French \& Spanish in the USA 
Table 2 Continued

\begin{tabular}{|c|c|c|}
\hline Source & Focus & Context \\
\hline Crookes \& & The sources of ESL teachers' & 20 ESL teachers in an intensive \\
\hline Arakaki (1999) & ideas for teaching & English program in the USA \\
\hline Cumming (1989) & $\begin{array}{l}\text { Student teachers' conceptions of } \\
\text { curriculum decision-making }\end{array}$ & 37 pre-service ESL teachers in Canada \\
\hline $\begin{array}{l}\text { Eisenstein-Ebsworth \& } \\
\text { Schweers (1997) }\end{array}$ & $\begin{array}{l}\text { Teachers' views on conscious } \\
\text { grammar instruction }\end{array}$ & $\begin{array}{l}60 \text { University teachers of ESL - } 30 \\
\text { in New York, } 30 \text { in Puerto Rico }\end{array}$ \\
\hline Farrell (1999) & $\begin{array}{l}\text { Student teachers' prior beliefs } \\
\text { about teaching grammar }\end{array}$ & $\begin{array}{l}34 \text { pre-service ESL teachers in Singapore, } \\
5 \text { of which are reported on }\end{array}$ \\
\hline Freeman (1993) & $\begin{array}{l}\text { Changes in teachers' practices and } \\
\text { thinking during teacher education }\end{array}$ & $\begin{array}{l}4 \text { high school French and Spanish } \\
\text { teachers doing an in-service teaching } \\
\text { degree in the USA. }\end{array}$ \\
\hline Gatbonton (1999) & $\begin{array}{l}\text { The patterns of pedagogical knowledge } \\
\text { of experienced ESL teachers }\end{array}$ & 7 ESL teachers in USA \\
\hline Golombek (1998) & $\begin{array}{l}\text { The personal practical knowledge of in-service } \\
\text { ESL teachers and its role in their practice }\end{array}$ & 2 ESL teachers on an MA in the USA \\
\hline Johnson (1992a) & $\begin{array}{l}\text { Instructional actions and decisions } \\
\text { of preservice ESL teachers }\end{array}$ & 6 pre-service ESL teachers in the USA \\
\hline Johnson (1992b) & $\begin{array}{l}\text { Teachers' theoretical beliefs about L2 } \\
\text { learning and teaching and their } \\
\text { practices during literacy instruction. }\end{array}$ & $\begin{array}{l}30 \text { ESL teachers in the USA; } \\
3 \text { secondary level ESL teachers chosen } \\
\text { from the original } 30\end{array}$ \\
\hline Johnson (1994) & $\begin{array}{l}\text { Preservice teachers' beliefs about L2 } \\
\text { learning and teaching and their perceptions } \\
\text { of their instructional practice }\end{array}$ & $\begin{array}{l}4 \text { preservice ESL teachers enrolled in } \\
\text { an MA in TESL course in the USA }\end{array}$ \\
\hline Johnson (1996) & $\begin{array}{l}\text { A novice's perceptions of initial } \\
\text { teaching experiences }\end{array}$ & 1 TESOL pre-service in the USA \\
\hline $\begin{array}{l}\text { Johnston \& } \\
\text { Goettsch (2000) }\end{array}$ & Teacher knowledge in explaining grammar & $\begin{array}{l}4 \text { experienced university ESL teachers in } \\
\text { the USA }\end{array}$ \\
\hline Lam $(2000)$ & $\begin{array}{l}\text { L2 teachers' reasons for using or not } \\
\text { using technology in their classrooms }\end{array}$ & $\begin{array}{l}10 \text { L2 teachers (English, Spanish \& French) } \\
\text { in Toronto }\end{array}$ \\
\hline MacDonald et al. (2001) & $\begin{array}{l}\text { Influence of a course in SLA on student teachers' } \\
\text { beliefs about English language learning }\end{array}$ & $\begin{array}{l}55 \text { undergraduate and postgraduate students on } \\
\mathrm{BA} / \mathrm{MSc} \text { programmes in TESOL in the UK }\end{array}$ \\
\hline Meijer et al. (1999) & $\begin{array}{l}\text { Teachers' practical knowledge about } \\
\text { teaching reading comprehension }\end{array}$ & $\begin{array}{l}13 \text { teachers in the Netherlands teaching } \\
\text { Dutch, English, Latin, French, \& German }\end{array}$ \\
\hline Meijer et al. (2001) & $\begin{array}{l}\text { Similarities and differences in } \\
\text { teachers' practical knowledge } \\
\text { about reading comprehension }\end{array}$ & $\begin{array}{l}69 \text { language teachers in the Netherlands } \\
\text { teaching Dutch, English, Latin or Greek, } \\
\text { German, \& French }\end{array}$ \\
\hline $\begin{array}{l}\text { Mitchell \& Hooper } \\
\quad(1992)\end{array}$ & $\begin{array}{l}\text { Teachers' views about place of } \\
\text { knowledge about language in the curriculum } \\
\text { and strategies for developing it }\end{array}$ & $\begin{array}{l}7 \text { state secondary school heads of English } \\
\text { and } 7 \text { of Modern Foreign } \\
\text { Languages in the UK }\end{array}$ \\
\hline $\begin{array}{l}\text { Mitchell et al. } \\
\qquad(1994 a ; 1994 b)\end{array}$ & $\begin{array}{l}\text { Teachers' models of knowledge } \\
\text { about language }\end{array}$ & $\begin{array}{l}7 \text { teachers of English, French, German, and } \\
\text { Spanish in state secondary schools in the UK }\end{array}$ \\
\hline Mok (1994) & $\begin{array}{l}\text { Experienced and inexperienced teachers' } \\
\text { reflections on their work }\end{array}$ & $\begin{array}{l}12 \text { teachers in the ESL department } \\
\text { of an American university }\end{array}$ \\
\hline Numrich (1996) & $\begin{array}{l}\text { Student teachers' perceptions of their } \\
\text { needs during a practicum }\end{array}$ & $\begin{array}{l}26 \text { novice ESL teachers enrolled in an } \\
\text { MA TESOL programme in the USA }\end{array}$ \\
\hline Nunan (1992) & $\begin{array}{l}\text { Experienced and inexperienced ESL } \\
\text { teachers' interactive decisions }\end{array}$ & 9 ESL teachers in Australia \\
\hline Peacock (2001) & $\begin{array}{l}\text { Changes in the beliefs about L2 learning } \\
\text { of trainee ESL teachers }\end{array}$ & 146 trainee ESL teachers in Hong Kong \\
\hline $\begin{array}{l}\text { Richards \& Pennington } \\
\quad(1998)\end{array}$ & $\begin{array}{l}\text { How ESL teachers coped with their } \\
\text { first year of teaching }\end{array}$ & $\begin{array}{l}5 \text { graduates of a } 3 \text { year BA TESL } \\
\text { course in Hong Kong }\end{array}$ \\
\hline Richards (1996) & The nature and role of the teachers' maxims & ESL teachers in Hong Kong \\
\hline Richards (1998b) & $\begin{array}{l}\text { Preactive and interactive decisions of experienced } \\
\text { and less experienced ESL teachers }\end{array}$ & 16 ESL teachers in Hong Kong \\
\hline Richards et al. (1992) & $\begin{array}{c}\text { The culture of teachers of } \\
\text { English in Hong Kong }\end{array}$ & $\begin{array}{l}249 \text { teachers of English in } \\
\text { Hong Kong secondary schools }\end{array}$ \\
\hline Richards et al. (1996) & $\begin{array}{l}\text { TEFL trainees' perceptions of and } \\
\text { development during a preservice } \\
\text { teacher education program }\end{array}$ & $\begin{array}{l}5 \text { teacher trainees on a certificate level } \\
\text { TEFL training course in Hong Kong }\end{array}$ \\
\hline
\end{tabular}


Table 2 Continued

\begin{tabular}{|c|c|c|}
\hline Source & Focus & Context \\
\hline Richards et al. (1998) & $\begin{array}{l}\text { Pedagogical reasoning of experienced } \\
\text { and less experienced teachers }\end{array}$ & $\begin{array}{l}10 \text { trainee teachers, } 10 \text { graduate TESL } \\
\text { teachers, and } 12 \text { practising teachers } \\
\text { in Hong Kong }\end{array}$ \\
\hline Schulz (1996) & $\begin{array}{l}\text { Student and teacher perceptions of } \\
\text { the role of grammar and correction } \\
\text { in language learning }\end{array}$ & $\begin{array}{l}824 \text { foreign language students } \\
\text { and } 92 \text { teachers (foreign languages, } \\
\text { ESL and Latin) at a university } \\
\text { in the USA }\end{array}$ \\
\hline Schulz (2001) & $\begin{array}{l}\text { Student and teacher perceptions of the role } \\
\text { of grammar and correction in language learning }\end{array}$ & $\begin{array}{l}607 \text { Colombian foreign language } \\
\text { students; } 122 \text { of their teachers }\end{array}$ \\
\hline $\begin{array}{l}\text { Sendan \& Roberts } \\
\text { (1998) }\end{array}$ & $\begin{array}{l}\text { The development of a student } \\
\text { teacher's personal theories } \\
\text { about teaching effectiveness }\end{array}$ & $\begin{array}{l}\text { One student EFL teacher on a } 4 \text { year } \\
\text { training programme in Turkey }\end{array}$ \\
\hline Smith (1996) & $\begin{array}{l}\text { The relationship between instructional decisions, } \\
\text { teachers' beliefs, and contextual factors }\end{array}$ & $\begin{array}{l}9 \text { experienced ESL teachers in adult } \\
\text { education institutions in Canada }\end{array}$ \\
\hline Spada \& Massey (1992) & $\begin{array}{l}\text { The relationship between the classroom } \\
\text { practice of novice L2 teachers and the } \\
\text { pedagogical knowledge they obtained } \\
\text { during teacher education }\end{array}$ & 3 novice ESL teachers in Canada \\
\hline Tercanlioglu (2001) & $\begin{array}{l}\text { Pre-service teachers' views of themselves as } \\
\text { readers and future reading teachers. }\end{array}$ & 132 pre-service EFL teachers in Turkey \\
\hline Tsui (1996) & $\begin{array}{l}\text { Change in a teacher's approach } \\
\text { to writing instruction }\end{array}$ & 1 ESL teacher in Hong Kong \\
\hline Ulichny (1996) & $\begin{array}{l}\text { The methodology of one ESL teacher } \\
\text { teaching a reading course }\end{array}$ & $\begin{array}{l}1 \text { ESL teacher in the USA \& } 18 \text { students } \\
\text { in an ESL reading class }\end{array}$ \\
\hline Woods $(1991 ; 1996)$ & $\begin{array}{l}\text { Planning and decision-making } \\
\text { in the ESL classroom }\end{array}$ & $\begin{array}{l}8 \text { ESL teachers in } 4 \text { university } \\
\text { settings in Canada }\end{array}$ \\
\hline
\end{tabular}

notions such as belief and knowledge is problematic. Researchers attempting this task have concluded as much; Grossman, Wilson \& Shulman (1989: 31), for example, set out to study what they perceived as teacher knowledge. Yet they concluded that 'while we are trying to separate teachers' knowledge and belief about subject matter for the purposes of clarity, we recognize that the distinction is blurry at best'. As we see later, Woods (1996) came to a similar conclusion. This is because, as Verloop et al. (2001: 446) explain, 'in the mind of the teacher, components of knowledge, beliefs, conceptions, and intuitions are inextricably intertwined'.

Thus throughout this paper I use the term teacher cognition as an inclusive term to embrace the complexity of teachers' mental lives. Studies of teacher cognition are taken here as those which examine what second and foreign language teachers, at any stage of their careers, think, know, or believe in relation to various aspects of their work (see Figure 1 for a list of possible aspects), and which, additionally but not necessarily, also entail the study of actual classroom practices (both preactive and interactive decision-making) and of the relationships between cognitions and these practices.

The review that follows is divided into two major parts. In the first I discuss language teacher cognition research with reference to the following three themes: (a) cognition and prior language learning experience, (b) cognition and teacher education, and (c) cognition and classroom practice. These were initially suggested by Figure 1 which, as I explained earlier, summarises key themes in the educational literature providing a conceptual antecedent to the work I review here. Subsequent analyses of the language teacher cognition literature revealed the recurrence of similar themes. The second part of the review focuses on studies of the two curricular aspects of language teaching - grammar and literacy which have been most researched from a teacher cognition perspective. My focus throughout the review will be substantive, though I will also comment on methodological issues. Table 2, by specifying topics, settings, and sample sizes for all the studies, also provides insight into the comparability of the work I review here.

\section{Teacher cognition and prior language learning experience}

Beliefs established early on in life are resistant to change even in the face of contradictory evidence (Nisbett \& Ross 1980). Such beliefs take the form of episodically stored material derived from critical incidents in individuals' personal experience (Nespor 1987), and thus teachers learn a lot about teaching through their vast experience as learners, what Lortie (1975) called their 'apprenticeship of observation'. 
Table 3 Terms in language teacher cognition research

\begin{tabular}{|c|c|c|}
\hline Source & Term & Description \\
\hline Borg (1998c) & Personal pedagogical systems & $\begin{array}{l}\text { Stores of beliefs, knowledge, theories, assumptions and } \\
\text { attitudes which play a significant role in shaping } \\
\text { teachers' instructional decisions }\end{array}$ \\
\hline Breen et al. (2001) & Pedagogic principles & $\begin{array}{l}\text { Shaped and generated by underlying and more abstract beliefs, } \\
\text { these service to mediate between beliefs and on-going } \\
\text { decision-making in particular instructional contexts }\end{array}$ \\
\hline Burns (1996) & Theories for practice & $\begin{array}{l}\text { The thinking and beliefs which are brought } \\
\text { to bear on classroom processes }\end{array}$ \\
\hline Crookes \& Arakaki (1999) & Routines & $\begin{array}{l}\text { Habitualized patterns of thought and action } \\
\text { which remove doubts about what to do next, reduce } \\
\text { complexity, and increase predictability }\end{array}$ \\
\hline Freeman (1993) & Conceptions of practice & $\begin{array}{l}\text { A set of ideas and actions teachers use to organise what } \\
\text { they know and to map out what is possible; they guide } \\
\text { individual action but are also affected by new situations }\end{array}$ \\
\hline Gatbonton (1999) & Pedagogical knowledge & $\begin{array}{l}\text { The teacher's accumulated knowledge about the teaching } \\
\text { act (e.g. its goals, procedures, strategies) that serves as } \\
\text { the basis for his or her classroom behaviour and activities }\end{array}$ \\
\hline Golombek (1998) & $\begin{array}{l}\text { Personal practical } \\
\text { knowledge }\end{array}$ & $\begin{array}{l}\text { A moral, affective, and aesthetic way of knowing } \\
\text { life's educational situations }\end{array}$ \\
\hline & Image & $\begin{array}{l}\text { A personal meta-level, organising concept in } \\
\text { personal practical knowledge in that it embodies a } \\
\text { person's experience; finds expression in practice; and } \\
\text { is the perspective from which new experience is taken }\end{array}$ \\
\hline Johnson (1992b) & Theoretical beliefs & $\begin{array}{l}\text { The philosophical principles, or belief systems, } \\
\text { that guide teachers' expectations about student } \\
\text { behaviour and the decisions they make }\end{array}$ \\
\hline Johnson (1994) & Images & $\begin{array}{l}\text { General metaphors for thinking about teaching } \\
\text { that not only represent beliefs about teaching but } \\
\text { also act as models of action }\end{array}$ \\
\hline Meijer et al. (1999) & Practical knowledge & $\begin{array}{l}\text { The knowledge teachers themselves generate as } \\
\text { a result of their experiences as teachers and } \\
\text { their reflections on these experiences. }\end{array}$ \\
\hline Richards (1996) & Maxims & $\begin{array}{l}\text { Personal working principles which reflect teachers' } \\
\text { individual philosophies of teaching }\end{array}$ \\
\hline Richards et al. (1992) & Culture of teaching & $\begin{array}{l}\text { The nature of teachers' knowledge and beliefs systems, their } \\
\text { views of good teaching, and their views of the systems in } \\
\text { which they work and their role within them }\end{array}$ \\
\hline Richards et al. (1998) & Pedagogical reasoning & $\begin{array}{l}\text { The process of transforming the subject } \\
\text { matter into learnable material }\end{array}$ \\
\hline Sendan \& Roberts (1998) & Personal theories & $\begin{array}{l}\text { An underlying system of constructs that student } \\
\text { teachers draw upon in thinking about, evaluating, } \\
\text { classifying, and guiding pedagogic practice }\end{array}$ \\
\hline Spada (1992) & $\begin{array}{l}\text { Specific pedagogical } \\
\text { knowledge }\end{array}$ & $\begin{array}{l}\text { Knowledge related specifically to the teaching } \\
\text { of a particular subject }\end{array}$ \\
\hline Woods (1996) & BAK & $\begin{array}{l}\text { A construct analogous to the notion of schema, } \\
\text { but emphasizing the notion that beliefs, assumptions, } \\
\text { and knowledge are included }\end{array}$ \\
\hline
\end{tabular}

Mainstream studies illustrate the influence on teachers' cognitions of their experience as learners (e.g., Holt Reynolds 1992); similar findings emerge from research with language teachers.

Bailey et al. (1996) describe a project in which seven MA candidates and a teacher educator investigated, through autobiographical writing and reflection on it, the role of their language learning histories in shaping their current teaching philosophies and practices. As a result, the writers identified several factors related to teaching and learning situations which had made their own language learning experiences positive: (1) teacher personality and style mattered more than methodology; (2) teachers were caring and committed, and had clear expectations of their students; (3) teachers respected, and were respected by, the students; (4) as students, their motivation to learn enabled them to overcome inadequacies in the teaching; and (5) learning was facilitated by a positive classroom environment. By 
exploring their experiences in this manner, the authors of this study felt they were able to begin to articulate their own theories of teaching and to become aware of their origins. They felt, quoting a similar study by Freeman (1992), that 'the memories of instruction gained through their 'apprenticeship of observation' function as de facto guides for teachers as they approach what they do in the classroom' (p. 11). Analyses of actual practices, however, were not reported here.

Johnson (1994) and Numrich (1996) do, however, shed light on how prior experience relates to classroom practice. Johnson found that preservice teachers' instructional decisions during a practicum were based on images of teachers, materials, activities, and classroom organisation generated by their own experiences as second language (L2) learners. She concludes that:

preservice ESL teachers' beliefs may be based largely on images from their formal language learning experiences, and in all likelihood, will represent their dominant model of action during the practicum teaching experience. (p. 450)

Numrich, working with novice teachers, found that teachers decided to promote or to avoid specific instructional strategies on the basis of their positive or negative experiences of these respective strategies as learners. For example, $27 \%{ }^{6}$ of the teachers reported in their diaries that they attempted to integrate a cultural component into their teaching because they had found learning about the L2 culture to be an enjoyable part of their L2 learning experiences. In contrast, the teachers noted that they avoided teaching grammar or correcting errors because their own experiences of these aspects of L2 instruction had been negative. With respect to the latter, Numrich reports that:

Error correction was most often cited as a technique that had been used by their language teachers and that had inhibited them from speaking. In some cases it had even turned them off to [sic] language learning because they had felt so humiliated and uncomfortable being corrected. Because of negative experiences of being corrected, several teachers chose not to interrupt their students' flow of speech in the classroom to correct errors (p. 139).

A teacher in Golombek (1998) also reported a similar wariness of correcting students as a result of her own negative experiences of being corrected as a L2 learner. Further evidence of how novice teachers' beliefs about language teaching can be shaped by their prior knowledge is provided in Farrell (1999), Almarza (1996), and Richards \& Pennington (1998), which I discuss in more detail elsewhere in this review.

${ }^{6}$ Readers are reminded to consult Table 2 for details of sample sizes.
Studies of practising teachers provide further support for the belief that prior learning experiences shape teachers' cognitions and instructional decisions. Woods (1996) reports on a teacher whose beliefs about L2 learning were influenced by the fact that while years of formal instruction in French did not enable him to communicate in the language, six months in the company of French speakers developed his ability to do so. As a result, this teacher developed beliefs about the superiority of communicative techniques over grammar-based techniques in promoting L2 learning. In a study of teachers' use of grammatical terminology (Borg 1999d), the metalinguistically rich, but communicatively unrewarding, grammar-based L2 education one teacher had experienced emerged as a contributing factor in her own decision as a teacher not to over-emphasise the use of terminology. In exploring teachers' beliefs about teaching grammar, EisensteinEbsworth \& Schweers (1997) also found that teachers' experiences as language learners were a significant influence. One teacher, for example, explained that 'my own education included very formal language study including memorization, reading, writing, and grammar. Now I'm using a communicative approach, but I won't completely abandon the teaching that worked for me' (p. 252).

The general picture to emerge here then is that teachers' prior language learning experiences establish cognitions about learning and language learning which form the basis of their initial conceptualisations of L2 teaching during teacher education, and which may continue to be influential throughout their professional lives.

\section{Teacher cognition and teacher education}

Mainstream educational research has shown that at the start of teacher education programmes, students may have inappropriate, unrealistic or naive understandings of teaching and learning (Brookhart \& Freeman 1992). Studies by Cumming (1989) and Brown \& McGannon (1998) illustrate this point in the field of language teaching. Cumming explored student teachers' conceptions of curriculum and concluded that these were inadequate as the basis of principled and effective program design in ESL. Students were asked to produce 'a schematic chart outlining the curriculum decisions they would consider to be most important in teaching an ESL course' (p. 35). The author reported that the charts produced by the student teachers were generally inadequate in terms of the relationships they posited between theoretical and practical issues, the way different components of the curriculum were related and sequenced, and the relative emphasis they placed on particular components. Brown \& McGannon (1998) administered a questionnaire 
about L2 acquisition (taken from Lightbown \& Spada 1993) to a total of 35 TESL and $\mathrm{LOTE}^{7}$ method students in the initial stages of their programme. Two beliefs held by both groups were that languages were learned mainly by imitation and that errors were mainly due to L1 interference. These beliefs were clearly inadequate as the basis for effective L2 pedagogy.

In terms of the impact of teacher education on teacher cognition, an influential review by Kagan (1992), often referred to in language teaching studies, suggested that the relationship is not significant. However, critiques of her synthesis by Dunkin (1995; 1996) have raised serious doubts about her conclusions. Nonetheless, the issue remains a central one to the study of teacher cognition ${ }^{8}$, and several studies have addressed it with reference to language teaching. In most cases researchers have concluded that teacher education did impact on trainees' cognitions, though the precise nature of this impact varied across studies and indeed even amongst different trainees in the same study.

Richards, Ho \& Giblin (1996) studied five trainees on an introductory practically-oriented teacher training course in Hong Kong and found changes in their cognitions in relation to (1) their conception of their role in the classroom, (2) their knowledge of professional discourse, (3) their concerns for achieving continuity in lessons, (4) common dimensions of the teaching they found problematic (e.g., timing, presenting new language), and (5) the manner in which they evaluated their own teaching. For example, with respect to the development of a professional discourse, the authors report that:

by the end of the course the trainees had completely internalized the discourse and metalanguage of the course and were able to talk spontaneously and thoughtfully about their own and others' lessons, to compare and contrast performances, and to discuss causes and effects of teaching behavior using the appropriate technical terminology. (p. 248)

The trainees, though, did not change in a homogeneous way; there was variability in the extent to which each of the trainees mastered the principles underlying the course, with each interpreting the course 'in individual ways on the basis of their teaching experiences and their own beliefs and assumptions about themselves, teachers, teaching, and learning' (p. 258).

The variable influence of teacher education on trainees is also shown in Almarza (1996), who tracked the learning of four student teachers on a $\mathrm{PGCE}^{9}$ course. In particular, the findings here highlight

\footnotetext{
7 Languages Other Than English.

${ }^{8}$ For a recent review of literature see Wilson, Floden \& FerriniMundy (2002).

${ }_{9}$ Postgraduate Certificate in Education.
}

the distinction between cognitive and behavioural changes which teacher education programmes may induce. Behaviourally, all four students adopted the specific teaching method they were taught on their programme, and implemented this in their classrooms during practice teaching. This behaviour, though, was at least partly a result of the need felt by the student teachers to conform to certain standards (they were, after all, being assessed). Cognitively, though, the student teachers varied in their acceptance of the suggested approach to teaching. These variations emerged when the students talked about their work, rather than through their practice, and were largely rooted in the different cognitions about language, learning and teaching they held prior to their training. For example, on completion of her teaching practice, one of the student teachers 'saw herself free from the constraints imposed by the context of the classroom, she was back in a position in which she could continue to explore the ideas she had about language prior to the beginning of the course' (p. 69). This study concludes that although teacher education played a powerful role in shaping the student teachers' behaviour during teaching practice, it did not alter significantly the cognitions the students brought to the course.

Freeman (1993) conducted a longitudinal study of changes in the practices of four foreign language teachers doing an in-service masters' degree which had as one of its specific aims the development of teachers' understanding of the professional discourse of education. Drawing on interviews, observations, and document analyses, the study describes the manner in which tacit conceptions of teaching held by the teachers emerged during the course in the form of tensions - defined as "competing demands within their teaching' (p. 488). The development of a professional discourse enabled the teachers to articulate and reflect on these tensions, and to reconceptualise their understandings of their practice in the process. The programme in this study had a clear impact on teachers' cognitions, though it is inconclusive regarding the effect of these cognitive changes on teachers' classroom practices; there was some evidence of behavioural change, though there were also patterns in the teachers' work which remained unmodified.

Even stronger claims about the manner in which trainees' cognitions do change during teacher education are provided by Sendan \& Roberts (1998) and Cabaroglu \& Roberts (2000). In the first of these studies, a key research question relevant to this review was 'what is the nature of observed changes (if any) in the structure and content of the student teachers' personal theories at different stages of the training programme?' (p. 234). Repertory grid data were used to represent changes in one student teacher's personal theories about teaching effectiveness over a period of 15 months. The distinction made here 
between changes in the content (i.e., what the trainee thought) and in the structure - 'the ways in which individual constructs are hierarchically organised into a whole system of construction' (p. 231) - was central to this study. An analysis of the grids generated at three points in the student teacher's progress through the course suggests that although there were no major changes in the content of his personal theories about effective teaching, there were clear developments in the organisation of this content. Underpinned by a basis of stable constructs, changes in the student teacher's thinking were characterised by the addition of new constructs, the reorganisation of the existing structures to accommodate these, the existence of 'mobile constructs' (p. 238), which were associated with different clusters of constructs at different times, and the formation of a more stable overall structure in which previously disassociated constructs were integrated into internally tight ones. On the basis of their findings, the authors argue that initial training does promote change in trainees' thinking, at least at the structural level. They conclude that:

the process of professional development is one in which new information and new experiences lead student teachers to add to, reflect upon and restructure their ideas in a progressive, complex and non-linear way, leading towards clearer organisation of their personal theories into thematically distinct clusters of ideas. It is therefore inappropriate to conceptualise student teacher cognitive development in terms of a simple process of aggregation of new ideas. (p. 241)

Cabaroglu \& Roberts (2000) used a sequence of three in-depth interviews to analyse the processes, rather than the content, of belief development in 20 PGCE Modern Languages students. They found that only one participant's beliefs remained unchanged during the programme. In this study, evidence of change emerged from the analysis of interview data, from which the authors established categories of belief development processes (listed with definitions and examples on p. 393). One category, for example, was called 're-ordering', defined as the 'rearrangement of beliefs regarding their importance'; a second was 're-labelling', which involves the renaming of a construct; a third example is 'reversal', the 'adoption of opposite of previous belief'.

In accounting for the widespread changes in beliefs found in this study, the authors suggest that opportunities early in the teacher education programme for student teachers to confront their preexisting beliefs were important, and they outline ways in which the programme they studied provide such opportunities. They conclude that contrary to views about conceptual inflexibility in student teachers' professional growth, the processes they described in their study are a more realistic picture of the changes that can occur during teacher education in student teachers' belief systems.

In contrast to the mainly qualitative work reported so far in this section, two questionnaire-based studies shed further light on cognitive change in language teacher education. MacDonald, Badger \& White (2001) examined the impact on students' beliefs of courses in second language acquisition (SLA). Most of the students in this study had little or no experience of teaching. The questionnaire about L2 acquisition from Lightbown \& Spada (1993) was administered before and after the SLA courses to a total of 28 postgraduates and 27 undergraduates. Before the course, the combined results showed that students agreed strongly with two of the 12 statements on the questionnaire; they did not disagree strongly with any of the statements though. After the course, students still agreed strongly with one of the statements they had strongly agreed with before the course: teachers should teach simple language structures before complex ones. Students also now disagreed strongly with three statements: languages are learned mainly through imitation; teachers should use materials that expose students only to those structures which they have already been taught; and students learn what they are taught. The authors conclude that after the course, the subjects had at least taken on board one of the few certainties afforded by SLA research: a rejection of the behaviourist model of learning' (pp. 956-57). Thus there is some evidence that the students' cognitions had been affected by the course ${ }^{10}$, though not all students' responses to the questionnaire showed belief change in the direction promoted by this course.

Peacock (2001) carried out a longitudinal study into the changes in the beliefs about L2 learning of 146 trainee ESL teachers over their 3-year BA TESL programme. The beliefs of first year trainees were collected using Horwitz's Beliefs About Language Learning Inventory (BALLI), and these were compared with the beliefs of experienced ESL teachers. Three key differences between trainees' beliefs and those of experienced teachers were identified in relation to the following statements:

- Learning a foreign language is mostly a matter of learning a lot of new vocabulary words.

- Learning a foreign language is mostly a matter of learning a lot of grammar rules.

- People who speak more than one language well are very intelligent.

10 These results could, though, simply be the product of students answering the questionnaire in a way which they felt best matched course content, which of course might not be indicative of any real cognitive change. 
In each case, the percentage of first year trainees agreeing with these statements was much higher than that for experienced teachers (e.g., only $7 \%$ of experienced teachers agreed with the second statement, compared to $52 \%$ of trainees). Such beliefs were seen by the author as 'detrimental to their [trainees'] own language learning or to their future students' learning' (p. 183) and he hoped that they would be eliminated in the course of the teacher education programme (where explicit attention was given to the nature of L2 learning). To monitor this, he asked the trainees to complete the BALLI at two further points in their course. On the basis of the results, Peacock concluded that 'there was surprisingly little change over the three years on Horwitz's two core beliefs about vocabulary and grammar, or ... about the role of intelligence in language learning' (p. 184) and that the 'data do not support the belief that trainees' beliefs are shaped by their preservice methodology courses' (p. 187). These conclusions contrast with those generally emerging from studies of teacher cognition in language teacher education.

\section{Summary}

The following are key themes to emerge from the research discussed in this section:

1. The notions of variable outcomes and individual developmental pathways seem central to an understanding of the impact of teacher education on language teacher cognition. Individual trainees make sense of and are affected by training programmes in different and unique ways. Further longitudinal studies of individual trainees' development on teacher education programmes, then, are to be encouraged.

2. The distinction between behavioural change and cognitive change during or as a result of teacher education, and of the relationships between the two, is key to continuing research on this topic. As we have seen here, behavioural change does not imply cognitive change, and the latter (as the discussion of contextual factors below suggests) does not guarantee changes in behaviour either.

3. Much existing literature about the ineffectiveness of teacher education in changing trainees' cognitions (i.e., beliefs, knowledge, attitudes) has focused on the content of these cognitions; this is the case with some of the studies I have reviewed here too. Work examining the processes and the structure of cognitive development, however, suggests significant changes in trainees do take place during teacher education. Continued research, then, can benefit from attention to the content, structure, and development processes involved in language teacher trainees' cognitive change.
4. These studies vary in what is considered to be evidence of cognition and cognitive change. Questionnaire responses, repertory grids, and indepth interview responses, for example, are very different forms of data, and the extent to which these and other forms of data can capture the content, structure, and change processes of cognitive phenomena is clearly an issue for continuing methodological discussion.

\section{Teacher cognition and classroom practice}

Numerous studies in mainstream educational research have shown that teacher cognition and classroom practice exist in 'symbiotic relationships' (Foss \& Kleinsasser 1996: 441). Several studies have also studied these relationships in the field of language teaching (Bailey 1996; Bartels 1999; Breen 1991; Breen, Hird, Milton, Oliver \& Thwaite 2001; Burns 1996; Gatbonton 1999; Golombek 1998; Johnson 1992a; Lam 2000; Nunan 1992; Richards 1996, 1998a, 1998b; Richards, Li \& Tang 1998; Smith 1996; Ulichny 1996; Woods 1991, 1996). Reflecting findings from the mainstream literature, these studies collectively show that language teachers' classroom practices are shaped by a wide range of interacting and often conflicting factors. Teachers' cognitions, though, emerge consistently as a powerful influence on their practices, though, as I discuss later, these do not ultimately always reflect teachers' stated beliefs, personal theories, and pedagogical principles.

As Table 4 shows, the cognitions shaping language teachers' classroom practices have been described in various ways in the studies listed above. These practices have been accounted for in terms of instructional concerns or considerations teachers have, principles or maxims they are trying to implement, their thinking about different levels of context, and the pedagogical knowledge they possess. In addition, the bases of teachers' instructional practices have been explained in terms of their personal practical knowledge (Golombek 1998), beliefs (Smith 1996; Woods 1991), and, as shown by Lam's (2000) study of L2 teachers' use of technology, teachers' personal convictions.

It is important to acknowledge (as I did in discussing Table 3 earlier) the different research traditions on which these studies draw. Though a more detailed analysis would identify a range of positions, two contrasting perspectives can be highlighted here. One derives from the educational literature on decision-making (see, for example, Shavelson \& Stern 1981), the second from that on teachers' personal practical knowledge (Elbaz 1981; Clandinin \& Connelly 1987). While both perspectives recognise the role of teachers' mental lives in shaping classroom events, the work on 
Teacher cognition in language teaching

Table 4 Cognitive influences on language teachers' classroom practices

Source

Cognitive influences

Bailey (1996)

Teachers' in-class decisions to depart from their lesson plan were based on a number of principles:

(1) serve the common good

(2) teach to the moment

(3) further the lesson

(4) accommodate students' learning styles

(5) promote students' involvement; and

(6) distribute the wealth

Breen (1991)

Seven pedagogic concerns, focused on three main variables:

Focus on the learners: concern with the learners'

(a) affective involvement

(b) background knowledge

(c) cognitive processes assumed to facilitate learning.

Focus on the subject matter: concern with language as

(a) usage

(b) use.

Focus on the teacher: concern with

(a) guidance

(b) classroom management.

Breen et al. (2001)

Burns (1996)

Five superordinate categories of teacher concern:

- a concern with how the learner undertakes the learning process

- a concern with particular attributes of the learner

- a concern with how to use the classroom and its human and material resources to optimize learning

- a concern with the subject matter of learning — with what is being taught and learned

- a concern with the specific contributions that they can make in their role as teacher

Three interacting contextual levels of teacher thinking:

- thinking about the institutional culture

- teachers' beliefs about language, learning, and learners

- thinking about specific instructional activities

Gatbonton (1999)

Six general domains of pedagogical knowledge:

- knowledge of how to manage specific language items so that students can learn them

- knowledge about the students and what they bring to the classroom

- knowledge about the goals and subject matter of teaching

- knowledge about techniques and procedures

- knowledge about appropriate student-teacher relationships

- knowledge about evaluating student task involvement and progress during the lessons

Johnson (1992a)

Eight categories of instructional considerations:

- student involvement and motivation

- instructional management

- curriculum integration

- student affective needs

- subject matter content

- student understanding

- student language skills and ability

- appropriateness of teaching strategy 
Table 4 Continued

- The maxim of involvement: follow the learners' interests to maintain student involvement

- The maxim of planning: plan your teaching and try to follow your plan

- The maxim of order: maintain order and discipline throughout the lesson

- The maxim of encouragement: seek ways to encourage student learning

- The maxim of accuracy: work for accurate student output

- The maxim of efficiency: make the most efficient use of classroom time

- The maxim of conformity: make sure your teaching follows the prescribed method

- The maxim of empowerment: give the learners control

decision-making adopts a somewhat technicist view of teaching which focuses on identifying the antecedents for teachers' interactive decisions and describing effective decision-making procedures. Several studies which I discuss here acknowledge this perspective (without necessarily endorsing a technicist view of teaching). The personal practical knowledge perspective examines teaching more holistically, taking into account, for example, the role of affective, moral and emotional factors in shaping teachers' classroom practices. This perspective is less explicitly adopted here, Golombek (1998) being a notable exception.

Looking beyond the terminological diversity evident in these studies and the range of conceptual traditions they reflect, though, several recurrent themes are apparent in this body of work and I discuss these in turn below.

\section{Common reasons for instructional decisions}

Studies have attempted to identify the reasons most commonly cited by teachers in explaining their instructional decisions. In Breen (1991), a concern for the cognitive processes which facilitated learning was the most common reason given ${ }^{11}$. In Gatbonton (1999), a concern for language management (e.g., explaining vocabulary, creating contexts for meaningful use) was overall the most common focus of teachers' pedagogical thoughts ${ }^{12}$. Johnson (1992a) reported that the preservice teachers in her study made most decisions to ensure student

\footnotetext{
11 This means that techniques were chosen by teachers in the belief that these techniques would engage the cognitive processes the teachers felt were most conducive to L2 learning.

12 This study also provides the interesting statistic that the two groups of teachers in the study averaged 3.48 and 3.77 pedagogical thoughts per minute respectively.
}

understanding and motivation as well as for instructional management reasons. She also concluded that 'unexpected student behavior is the prominent antecedent condition of preservice teachers' instructional behavior' (p. 527). Nunan (1992), in contrast with Gatbonton, found that teachers' comments on their decisions did not reveal a concern for language (especially in the case of the inexperienced teachers in his study); in this case, teachers' concerns related mostly to the pacing and timing of lessons, the quantity of teacher talk, and the quality of their explanations and instructions. Richards (1996) analysed data from a corpus of teacher narratives and interviews (without, however, analysing actual teaching) to suggest that teachers accounted for their pedagogical choices with reference to maxims (i.e., personal working principles - see Table 4). Similar principles were reported in the work of Bailey (1996), which I discuss below.

\section{Departures from lesson plans}

The notion of improvisational teaching has been examined in the educational literature (e.g., Borko \& Livingston 1989) and studies of language teacher decision-making have also looked specifically at the reasons teachers give for departing from their lesson plans. Ulichny (1996) presents a case study of a teacher who started a lesson with specific plans and principles in mind (e.g., promoting learner-centred reading) but who during the lesson had to modify her plans in the face of the unexpected difficulties the students experienced in completing the planned activities. The outcome was a lesson in which the teacher engaged in practices which did not reflect her principles (e.g., the lesson became very teachercentred). Bailey (1996) found that teachers' in-class decisions to depart from their lesson plans were based on a number of principles (see Table 4). 
For example, one principle was 'serve the common good'. This means that when an unexpected issue or question arises during a lesson, a teacher may depart from the plan to deal with it if it is perceived to be of general relevance to the whole class. In his study of teachers' use of lesson plans, Richards (1998b) also found evidence of 'on-the-spot modification of planned activities in order to maintain students' engagement and interest level' (p. 115). These modifications (more common in the work of experienced teachers) were prompted by pedagogical factors (e.g., the need to simplify a task) and by a perceived need for more focused language work. Smith (1996) too highlights the distinction between planned and unplanned interactive decisions; in her study, unanticipated decisions were prompted by student factors (e.g., students' affective state) or teacher factors (e.g., forgetting to bring a key resource to class). Smith reports that student misbehaviour and student noncomprehension, two factors typically associated with unplanned interactive decisions, were not in evidence in the classes she studied. Rather than seeing teachers' departures from lesson plans as a shortcoming in their work, then, teacher cognition research shows that such departures are the result of the constant interaction between teachers' pedagogical choices and their perceptions of the instructional context, particularly of the students, at any particular time.

\section{Cognition and context}

In Borg (1998c) I referred to several studies from the educational literature which show that teachers' practices are also shaped by the social, psychological and environmental realities of the school and classroom (this phenomenon is also highlighted in the framework provided in Figure 1). These factors include parents, principals' requirements, the school, society, curriculum mandates, classroom and school layout, school policies, colleagues, standardised tests and the availability of resources. There is evidence to suggest that, unsurprisingly, such factors may also hinder language teachers' ability to adopt practices which reflect their beliefs. Burns (1996: 162), for example, talks about the 'organisational exigencies' of the context in which the teacher she reports on worked, and of the ways the teacher's awareness of the broader institutional context had an impact on decisions about lesson planning and content. In their study of novice teachers, Spada \& Massey (1992) found differences in the extent to which classroom practices reflected the principles the novices were taught in their teacher education programme, and suggest that this may have been due to the contextual factors of the school in which different teachers worked. Contrasting two teachers, they write that:
It will be recalled that Alice was teaching in a private school and given considerable flexibility as to what she could do in her classroom. It was a tranquil school setting with exemplary behaviour exhibited on the part of the students. It is possible that this factor was an important one in that it enabled Alice to use the knowledge she obtained in her training and concentrate on the development and application of her lessons in creative ways without any distractions. Neil, on the other hand, was teaching in a public school known to have serious discipline problems. As indicated earlier, this meant that he was rarely able to follow through with his lesson plans and spent most of his time managing student behaviour. (p. 33)

The reference to discipline problems is interesting here as, in contrast to the attention it has received in mainstream educational research, problem behaviour rarely seems to be an issue in the classrooms described in the literature on language teacher cognition. This, of course, is a reflection of the fact that much of this research has been conducted in language learning settings which are not necessarily, in a global sense, typical (e.g., small classes with adult learners in universities or private institutions).

Crookes \& Arakaki (1999) also found strong evidence that difficult working conditions affected what language teachers did; in their study, teachers had to cope with heavy workloads (approximately 50 hours a week), which meant that time for preparation was limited. This had a powerful impact on teachers' pedagogical choices. As one teacher explained, 'I will often choose or create an exercise [even though] I know there could be a better one, but I just can't do it within the time that I have' (p. 18). Further evidence of how context may conflict with cognition comes from Johnson (1996), who reports on a student teacher on a practicum who finds herself struggling to adopt practices which reflected her principles. In this case, there was a key tension between covering all the material and dealing with students' questions, and with the need for coverage exerting a powerful influence the teacher found she was unhappy with her practices:

I don't like it when I see myself teaching this way. I want it to be more student-centred and not teacher-centred, but sometimes it's just easier to stand up there and tell them what they need to know. This is not my vision of good teaching but sometimes I find myself doing it anyway. (p. 37)

Johnson reports how the teacher's initial enthusiasm was gradually overcome by what she saw as contextual realities she felt were beyond her control. One final example to mention here of how context can constrain what language teachers do is provided by Richards \& Pennington's (1998) study of teachers in their first year of teaching in Hong Kong. These teachers had been trained in a version of the communicative method, yet almost without exception their practices during their first year diverged from communicative principles. This was due to the impact of large classes, 
unmotivated students, examination pressures, a set syllabus, pressure to conform from more experienced teachers, students' limited proficiency in English, students' resistance to new ways of learning, and heavy workloads. As the authors conclude:

Such factors discourage experimentation and innovation, and encourage a 'safe' strategy of sticking close to prescribed materials and familiar teaching approaches. Without any relief from these factors and without any reward for innovating in the face of them, the teachers would naturally be led back toward a conservative teaching approach to align themselves with the characteristics of the existing teaching context. (pp. 187-88)

\section{Cognition and experience}

As suggested by Figure 1, cognition not only shapes what teachers do but is in turn shaped by the experiences teachers accumulate. Although no studies of language teachers have specifically examined this issue, several do refer to the impact of experience on cognition (e.g., Breen et al. 2001; Mok 1994). Crookes \& Arakaki (1999) discuss this issue in some detail; in examining the sources of ESL teachers' ideas, they found that accumulated teaching experience was the source cited most often by the teachers in their study. They report that:

many of these teachers spoke about their teaching experience as being a personally unique and self-contained entity .... It was a personal history of knowledge and information gained through trial and error, concerning which teaching ideas (and their sources) were effective in which circumstances. As one veteran teacher stated simply, 'As you have more practice, then you know in the classroom what will work and what will not work.' (p. 16)

Studies comparing experienced and less experienced language teachers also shed light on transformations in teacher cognition which may occur over time. Earlier, I referred to the finding by Nunan (1992) that experienced language teachers' decisions showed greater attention to language issues than those of less experienced teachers, who were more concerned with classroom management. This suggests that with experience teachers learn to automatise the routines associated with managing the class, and can thus focus more attention on issues of content. Richards (1998b) also found that experienced teachers engaged in more improvisational teaching than inexperienced teachers. He argues that 'this suggests that as teachers develop their teaching skills, they are able to draw less on preactive decision-making (the type of planning that occurs prior to teaching) and make greater use of interactive decision-making as a source of their improvisational performance' (pp. 117-118). In comparing novice and experienced teachers' approaches to a reading lesson and to teaching literature, Richards, Li \& Tang (1998) also identified four areas of language teaching which novice teachers were less skilled at: (a) thinking about the subject matter from the learner's perspective; (b) having a deep understanding of the subject matter; (c) knowing how to present subject matter in appropriate ways, and (d) knowing how to integrate language learning with broader curricular goals.

None of the above studies, however, were longitudinal and thus one can only deduce some of the possible processes language teachers go through in developing the cognitions and skills more characteristic of experienced teachers. Woods (1996) does, though, provide a more detailed example which shows how a teacher's understandings of L2 teaching - particularly his notion of the roles of teachers and learners - changed over time as a result of the difficulties he experienced teaching Japanese students. This teacher initially equated the notion of 'purpose' in language learning with providing students with opportunities for communicative practice in the classroom; when students failed to respond to this approach, he gradually broadened his view of purpose so that it included students' perceptions of the purpose of their studies (in this case, passing an exam). Consequently, he modified the manner in which he approached L2 instruction with these students.

\section{PPK, BAK, and pedagogic principles}

Three further studies merit special comment here (Breen et al. 2001; Golombek 1998; Woods 1996); not only do they go beyond the study of instructional decisions as described above, but they also extend, conceptually and methodologically, our understandings of the relationships between language teachers' cognitions and practices.

Golombek (1998) takes the notion of personal practical knowledge (PPK) from mainstream educational research and uses this as the basis for an examination of the practices of two ESL teachers. The accounts presented go beyond an analysis of interactive decisions and of the immediate factors motivating these; rather, the study shows how the teachers' work was shaped by four overlapping and interacting categories of PPK (knowledge of self, of subject matter, of instruction, and of context) which the teachers held and used in a holistic manner. Echoing Freeman's (1993) use of the term, Golombek shows the working of these categories by exploring tensions in the teachers' work. For example, in one case the tension is discussed in terms of the teacher's desire to achieve a balance in her lessons between attention to both accuracy and fluency; however, her own negative experiences of language learning, where she was hypercorrected, discourage her from attending to accuracy as much as she would like to (and is expected to) for fear of making her students feel bad too. The multifaceted nature of this teacher's PPK surfaces as she articulates and attempts to make sense of this 
tension. The study illustrates how L2 teachers' PPK is 'personally relevant, situational, oriented towards practice, dialectical, and dynamic as well as moralistic, emotional, and consequential' (p. 452) and concludes that classroom practice and PPK exert a powerful and continual influence on one another:

The teachers' personal practical knowledge informed their practice by serving as a kind of interpretive framework through which they made sense of their classrooms as they recounted their experiences and made this knowledge explicit. The teachers' sense-making processes were dynamic; the teachers' practice at any point represented a nonlinear configuration of their lived experience as teachers, students, and people, in which competing goals, emotions, and values influenced the process of and the classroom strategies that resulted from the teachers' knowing. Thus, personal practical knowledge informs practice, first, in that it guides teachers' sense-making processes; that is, as part of a teacher's interpretive framework, it filters experience so that teachers reconstruct it and respond to the exigencies of a teaching situation. Second, it informs practice by giving physical form to practice; it is teachers' knowledge in action. Because teachers use this knowledge in response to a particular context, each context reshapes that knowledge. In this way, L2 teachers' personal practical knowledge shapes and is shaped by understandings of teaching and learning. (p. 459)

Woods (1996) conducted a longitudinal study of planning and decision-making in ESL classrooms in Canada. Drawing on interviews, observations, videobased stimulated recall, teachers' logs, and document analysis, this study tracked a group of teachers as they went through the process of planning and teaching their courses. This work provides detailed insight into teachers' decision-making processes and the factors shaping these. These factors relate not only to immediate antecedent conditions, but also to influences stemming from teachers' professional lives as a whole (e.g., their prior language learning experiences). Woods divides these factors into two groups, which he labels external and internal:

External factors are situational factors which teachers take into account in making decisions (or to be accurate, what teachers know, assume and believe about these factors). Internal factors are ones internal to the decision-making process itself, i.e., the internal structuring of decisions and the relationships of decisions to each other. (p. 128)

As an example of the complex range of external factors which impact on the decision-making process, Woods (p. 129) cites the following list which emerged from the analysis of one teacher's approach to planning a lesson:

- how many students will probably turn up

- availability of photocopying

- knowledge about students' prior course experience

- a recent conversation with another teacher

- estimation of the complexity of a task

- estimation of how well the students as a group are moving

- estimation of what the group can handle
- estimation of how well particular individuals in the class are moving

- estimation of what particular individuals can handle

- class dynamics and individual dynamics in class

Internal factors relate to temporal and logical relationships amongst instructional decisions. Teachers need to organise instruction chronologically and hence to make decisions about what comes first, what follows, and so on. Logical relationships refer to the different levels of generality at which planning occurs (e.g., course, lesson, activity, text); teachers' decisions are thus also shaped by their understandings of the relationships among different levels of course units.

Woods' data also highlighted for him the problems I mentioned early in this paper inherent in attempting to distinguish between constructs such as belief and knowledge. He thus proposed the notion of BAK (beliefs, attitudes, knowledge) to reflect his view that, rather than being distinct concepts, beliefs, assumptions, and knowledge are points on a spectrum of meaning.

The study by Breen et al. (2001) also makes a distinctive contribution to our understanding of the relationships between cognition and practice in language teaching. Through observations and elicitation procedures, five researchers examined the relationship, at both an individual and group level, between the practices and principles of 18 teachers working in a similar context in Australia. An analysis of the profiles generated by this study showed that individual teachers realise specific principles through particular sets of favoured practices, and that at an individual level these configurations of practices and principles are unique. At group level, though, there were several pedagogic principles which were common to the majority of the teachers (e.g., a belief in the importance of taking individual differences among students into account). An analysis of the practices which were justified by the teachers with reference to these shared principles showed that any one principle was realised through several distinct practices (see Figure 2 for an example).

However, the set of practices related to any one principle was largely distinct from the set related to a different principle. The study thus showed that teachers working in a similar context may implement a set of shared principles through diverse practices, but that behind this apparent diversity of practices there is 'a collective pedagogy wherein a widely adopted classroom practice is... an expression of a specific and largely distinctive set of principles' (p. 496).

\section{Summary}

In this third main section of the review, I have discussed relationships between cognition and practice in language teaching with respect to five issues: (a) 
- Shows interest in students' personal lives; e.g., asked about a student's relative who was sick

- Accepts all students' responses without saying they're wrong: 'You would be understood, but a better way to say that is...'

- Integrates within lessons items needed for competencies to be covered in the term

- Assesses students individually when they say they are ready

- Goes from individual to individual during desk work to check understanding or correctness

- Makes worksheets on same topic but at different levels

- Links vocabulary/concepts back to students' culture/experience (e.g., 'gnome': do they have similar creatures in their culture)

- Models orally and on board as visual support

- Uses colours to mark inflections of words on board

- Uses variety of resources: video, tapes, \& workbook cxercises

- Accompanies oral input with written, pictorial, diagrammatic, input using colour coding

- Uses videos, real experiences, tapes, gesture, mime, groupwork

- Listens to everyone. asks their opinions, asks when they want a break

- Incompleted homcwork, inability to do a task, or being late to class not admonished by the teacher(s)

- Pairs stronger person with one with less developed English

- Negotiates breaks and outings

- Explains detailed rules, exceptions, generalizations

- Much input to whole class, especially feedback when groups reporting back

- Chooses topic that is seen as relevant to students' daily lives ('fast foods')

- Corrects sentences in students' writing

- Uses students' names to illustrate comparative/superlative forms of adjectives

- Chooses topics that are 'jazzy/groovy' to suit $18-20$ age group

- Video replay of students' own oral presentations

- Adopts informal, non-authoritarian manner

- Explains how a person could take a book from the local library

- Gets feedback from students on their community involvement (e.g., conversations with other parents at their children's school)

Figure 2 Practices realising the principle of accounting for individual differences (Breen et al. 2001, p. 490)

reasons for teachers' decisions; (b) teachers' departures from their lesson plans; (c) cognition and context; (d) cognition and experience; and (e) PPK,
BAK, and pedagogic principles. Before proceeding I will outline some issues which emerge from the above discussion. 
1. Decision-making is the most researched aspect of language teacher cognition. Studies have approached this issue from various perspectives, though there is a shared interest in describing the kinds of decisions language teachers make and understanding the reasons (usually immediately antecedent ones) for them. More research, though, into the less immediate factors behind language teachers' decisions - e.g., prior learning and professional experience - is required. Such work, drawing on notions such as personal practical knowledge, would contribute to a more holistic understanding of language teachers' practices and cognitions.

2. This body of work is characterised by conceptual, terminological and definitional variability. Though understandable during the decade of change in this field of research, the emergence of unifying, rather than disparate, frameworks for understanding language teacher's cognitions and practices would seem to be an appropriate goal as we move into our decade of consolidation in this domain of research.

3. As Burns (1996) argues, greater attention to the social and institutional contexts of classrooms is required in studies of what language teachers do. In some of the studies above, little reference is made to the contextual factors which may have facilitated or hindered the kinds of decisions teachers were able to make. In the light of what we know about the impact of contextual factors, Bailey's (1996) admission that 'the small and highly interactive classes, the teachers' preparation, and the use of a teacher-controlled syllabus and flexible materials all may have influenced their decision making' (p. 24) downplays what were inevitably powerful influences on the outcomes of her study. In particular, the extent to which teachers have to follow a set curriculum (as in the studies of Hong Kong teachers) or are free to develop their own courses (as in the studies by Bailey and Woods, for example) seems to be crucial in understanding the decisions language teachers make.

4. Related to this point, there is also a need for more research in contexts which, globally speaking, are more representative of language classrooms. I am thinking here of classrooms in state schools, taught by non-native teachers, and where syllabuses are to various degrees prescribed. Hardly any of the settings studied in research I have reviewed here reflect these characteristics.

5. Further research into the processes through which language teachers' cognitions and practices are transformed as they accumulate experience is also required. Much existing insight into this issue is based on comparisons of experienced and novice teachers; longitudinal enquiries of how teachers actually change would be an important addition to existing research here.
6. Most current research highlights the idiosyncratic nature of language teachers' cognitions and practices. While continued attention to the study of individual cases will remain central to this field, the search for patterns of cognitions and patterns amongst groups of teachers working in similar contexts is another direction for further research.

7. None of the research reviewed here attempts to explore relationships between cognitions, practices, and learning outcomes. The lack of attention to learning has probably been a reaction to the process-product models of research on effective teaching which dominated the literature for many years; in these studies, learning outcomes were all that mattered, and the teachers' active role in shaping what happened in the classroom was ignored. Now that teacher cognition research is wellestablished, though, it is time to consider how what language teachers think, know, and do, relates to learning. ${ }^{13}$

8. An important methodological issue in studying teachers' practices is the extent to which accounts of their instructional decisions which teachers provide after lessons capture the interactive thinking occurring during the lessons. Teachers' accounts may be retrospective and/or ad hoc rationalisations of what they did largely unconsciously, and these rationalisations may also be shaped by the manner in which the researcher prompts teacher to reflect on their work. Bailey (1996), for example, comments on this issue, but it is one that merits further consideration in continuing work of this kind.

9. One final methodological observation is that it is positive to see that teacher cognition in language teaching has generally been studied with close attention to what happens in classrooms. This may seem an obvious requirement for research which is ultimately aimed at developing better understandings of teaching. However, earlier work in teacher cognition had been criticised (see, for example, Kagan 1990; Richardson, Anders, Tidwell, \& Lloyd 1991) for relying on paper and pencil measures of teacher cognition (e.g., questionnaire responses) without examining these in relation to practice. The research I have reviewed so far is, in most cases, not open to such criticism.

I will now proceed to discuss two curricular areas grammar teaching and literacy - which have been specifically focused on in language teacher cognition research.

13 This is, though, one of the themes being explored as part of the Teacher Knowledge project at the School for International Training, Vermont, USA, under the directorship of Donald Freeman. This project is not concerned solely with language teaching. See http://www.sit.edu/tkp/index.html. 


\section{Teacher cognition in teaching grammar}

Several studies of teacher cognition in relation to grammar teaching now exist. These are discussed below under the following headings: (a) teachers' knowledge of grammar; (b) teachers' beliefs about teaching grammar; and (c) practices and cognitions in teaching grammar.

\section{Teachers' knowledge of grammar}

Several studies in English education contexts in the UK have highlighted inadequacies in the knowledge of grammar and general understandings of language of prospective and practising language teachers (e.g., Chandler, Robinson, \& Noyes 1988; Williamson \& Hardman 1995; Wray 1993). Andrews (1994; 1999a) has examined similar issues in EFL contexts. His 1994 study concluded that according to 82 trainers surveyed, more than $50 \%$ of the trainees they had encountered had inadequate levels of grammatical knowledge/awareness. Using a 60-item test, Andrews (1999a) also compared the explicit knowledge of grammar and grammatical terminology of groups of native and non-native speaker prospective and practising language teachers in Hong Kong and the UK. Amongst other findings, Andrews found that the non-native teachers of English (with a total mean score of around 70\%) did significantly better on the test than the other groups overall. The native speaker group of undergraduate students studying English studies performed worse of all with an overall average score of less than $41 \%$, a finding which reflects the low levels of grammatical knowledge reported in the UK studies I mentioned above.

\section{Teachers' beliefs about teaching grammar}

Here I discuss studies which have examined teachers' beliefs about grammar teaching without however directly studying actual classroom practices. An extensive analysis of teachers' perspectives on grammar teaching was conducted by Eisenstein-Ebsworth \& Schweers (1997), who used questionnaires with 60 University teachers of ESL in New York and Puerto Rico, and informal interviews with eight of these, to explore their views about conscious grammar instruction. The majority of the teachers felt grammar should be taught at least sometimes, with the Puerto Rico teachers more in favour of conscious instruction than the New York group. This was explained partly in terms of the more traditional approach to language teaching generally advocated in Puerto Rico; as one teacher in the latter group explained, 'grammar has always been part of our language learning experience. We see no reason to abandon it totally' (p. 247). The study found that teachers generally had well-defined approaches to teaching grammar that they were confident in and were able to provide a coherent rationale for. In articulating their rationales, teachers referred to various factors shaping their views, such as student wants and syllabus expectations. However, it was their experience as teachers and learners which emerged again here as a particularly powerful influence on their views about grammar teaching, and the study concludes that 'it is interesting that our participants rarely justified their approaches by referring to research studies or any particular methodology' (p. 255)

Two large-scale studies by Schulz (1996; 2001) explored both teachers' and students' attitudes towards the role of grammar and corrective feedback. The first study compared the attitudes to grammar teaching and corrective feedback of 92 FL teachers and 824 language learners at an American university. Supporting the findings of Cathcart \& Olsen (1976) and McCargar (1993), this study revealed significant mismatches between teachers' and students' views about error correction. For example, 94\% of the students disagreed with the statement 'teachers should not correct students when they make errors in class', while only $48 \%$ of teachers did. $90 \%$ of the students also said they would like to have their spoken errors corrected, compared to $42 \%$ of the teachers who agreed that students' oral errors should be. Schulz (2001) replicated this study with $122 \mathrm{FL}$ teachers in Colombia, together with 607 of their students. Results on this study were consistent with the patterns in the US study.

In addition to comparing teacher and student views on error correction, Schulz also explored respondents' views about how FLs are learned. Her US study revealed 'perturbing differences' (p. 348) between student and teacher opinions on this issue. For example, while $80 \%$ of the students believed that 'the formal study of grammar is essential to the eventual mastery of the language', only $64 \%$ of the teachers shared this view. In the follow-up study with Colombian participants, the differences in teacher and student opinion about how FLs are learned were even more pronounced. For example, while $76 \%$ of the students said they liked grammar, only $30 \%$ of the teachers felt students did.

Schulz concluded that teachers should find out about their students' views as such mismatches, particularly about the role of formal instruction and error correction, may reduce the 'pedagogical face validity' (1996: 349) of instruction in the eyes of the learners, impinge negatively on student motivation, and consequently be detrimental to learning.

Also concerned with this need for congruence between teacher and student cognitions, Berry (1997) used a 50-item questionnaire to measure the knowledge of grammatical terminology of undergraduate students in Hong Kong, and asked teachers of these students to indicate whether they felt the students knew the terminology covered in the questionnaire. He found 'wide discrepancies between students' knowledge of metalinguistic terms 
and between this and the teachers' estimation of it' (p. 143). In fact, teachers overestimated students' knowledge of terminology on 16 out of the 50 items on the test. Again, Berry concludes that this mismatch between student knowledge and teachers' assumptions about it could cause serious problems in the classroom.

Burgess \& Etherington (2002) used a questionnaire to examine the beliefs about grammar and grammar teaching held by 48 teachers of English for academic purposes (EAP) in UK universities. Overall, the teachers in this study reported positive attitudes towards formal instruction; they felt it had a contribution to make to the development of their (normally advanced) EAP students' proficiency and that conscious knowledge of grammar played a role in these students' use of language (as the authors note, the absence of more detailed qualitative data precluded further insight into what the teachers thought this role might be). Over $90 \%$ of the teachers in this study reported that their students expected them to present grammar points explicitly, and the teachers here were generally positively disposed to this expectation. This concurrence of views between EAP students and teachers contrasts with Schulz's findings mentioned above, although crucially the latter were based on data from both students and teachers, not just from teachers as in the EAP study. This methodological difference suggests that comparisons between the work of Schulz and that of Burgess \& Etherington need to be made very cautiously.

\section{Practices and cognitions in teaching grammar}

Farrell (1999) asked pre-service teachers of English in Singapore to write about their past experience of learning English and about their personal views about teaching grammar, and to decide whether to adopt an inductive or a deductive approach to formal instruction. Trainees' accounts highlighted the manner in which their choices were influenced by their prior language learning experiences. Thus, for example, some students wrote that they were inclined to approach grammar in the way they had been taught it themselves (inductively or deductively) because it was effective (even though in some cases it may have been boring).

Further insight into connections between cognitions and practices in grammar teaching is provided in the work of Brumfit, Mitchell, and Hooper (1996; Mitchell, Brumfit, \& Hooper 1994a, 1994b; Mitchell \& Hooper 1992). This work described knowledge about language (KAL) practices in secondary English and Modern FL classrooms in the UK, and documented teachers' beliefs about language and about the role of explicit KAL in language education ${ }^{14}$. Findings here highlighted significant differences between English and FL teachers; FL teachers viewed KAL largely in terms of sentence-based explicit grammar work, something they felt made a 'direct contribution...to the development of pupils' target language proficiency' (Brumfit et al. 1996: 77). This was reflected in their classroom practices; for example, in the case of one teacher of French, 23 out of 30 observed episodes of language work focused on language as a system. English teachers, in contrast, adopted a textbased, functional approach to language work, rarely conducting explicit grammar work and reporting that this was of marginal relevance to the development of students' overall linguistic ability (Mitchell et al. 1994b; Mitchell \& Hooper 1992).

These findings suggested that the FL teachers in particular had been influenced relatively little by those theories of second-language acquisition that downgrade the role of explicit, form-focused instruction in the learning of a foreign language' (Mitchell et al. 1994a: 197). The conclusions emerging from this work tally somewhat with those in Eisenstein-Ebsworth \& Schweers (1997) regarding the minimal role which an awareness of research into SLA seems to play in FL teachers' rationales for their approach to explicit language work.

In exploring the concept of teachers' metalinguistic awareness (TMA), Andrews (1997; 1999b) has also shed some light on connections between teachers' cognitions and practices in teaching grammar. In his 1997 study, he explored the role TMA played in explanations of grammar by asking practising and prospective teachers of English in Hong Kong to participate in a controlled role play $^{15}$ in which, individually, they were given texts with obvious formal errors in them and asked to identify these and to act out in front of the researcher the subsequent explanation they would give learners. Although the study highlighted weaknesses in the participants' KAL, Andrews argues that 'many of the apparent weaknesses in the performances...seem to relate to metalinguistic awareness in operation rather than to problems with the underlying declarative KAL' (p. 160). For example, some teachers who identified errors in the text were subsequently unable to formulate explanations of them in language their learners would find helpful. Andrews concludes that discussions of teachers' metalinguistic awareness should account for both its declarative and procedural dimensions, and that 'assessing teachers' metalinguistic awareness solely by focusing on declarative language awareness may miss out on procedural problems' (p. 160).

\footnotetext{
14 Pupils' understandings of KAL were also explored but I do not report on these here.

${ }^{15}$ Thus this study analysed simulated rather than actual teaching.
} 
Extending this work, Andrews (1999b) argued that TMA might be 'a specifically language-related facet of L2 teacher competence' (p. 176) which affects teacher's ability to transform language from, for example, instructional materials, into appropriate linguistic input for learners. For example, one teacher in this study demonstrated inadequate TMA by adopting 'an unaware, uncritical, diffident acceptance of all that the materials say' (p. 175) with the result that such materials, despite obvious deficiencies, became learner input without any modification by the teacher. In contrast, a second teacher recognised and filtered such deficiencies, transforming the materials in such a way that the input learners received was more effective.

Major insights into L2 teachers' actual practices in teaching grammar and the cognitions underlying these practices also emerge from studies by Borg (1998b; 1998c; 1999a; 1999c; 1999d; 2001) ${ }^{16}$ and Johnston \& Goettsch (2000). These studies describe real classroom events and use these as the basis of discussions with teachers through which teachers' emic (i.e., insider) perspectives on the teaching of grammar are made explicit.

Borg studied five EFL teachers in Malta, and several new insights into teachers' cognitions and practices in formal instruction emerged from this work. For example, the data suggest that the decision to conduct explicit formal instruction does not necessarily imply a belief on the teacher's part that such instruction promotes language learning; the teacher in Borg (1998c) was not convinced this was the case but integrated some explicit work into his teaching because he felt the students expected and would respond positively to it. Another key finding was that in teaching grammar teachers do not necessarily adhere exclusively to one particular approach; one of the teachers in Borg (1999c), for example, employed both deductive and inductive strategies in teaching grammar, justifying these with reference to interacting and sometimes conflicting beliefs based on her own teaching and learning experience.

Borg (1998b) explored the approaches to 'meta talk' (instructional talk about language) adopted by two teachers. The teachers' practices were analysed in terms of five features: how a focus for meta talk was defined, the modes of interaction used during such talk, the procedures followed in examining language, the occurrence of metalanguage, and the nature of the outcomes of meta talk. An analysis of these practices and of the psychological, pedagogical, and situational factors shaping them supported the claim that 'meta talk in the FL classroom is by no means a monolithic phenomenon' (Faerch 1985: 197). One specific aspect of meta talk, the use of grammatical

16 These papers report specific issues emerging from one larger study (Borg, 1999b). terminology - another issue widely debated in the literature without any reference to teachers' actual practices and cognitions - was investigated in more detail in Borg (1999d). A comparison of the role of terminology in the work of four teachers highlighted both variety in their practices as well as personalised stances towards the use of terminology shaped by their unique educational biographies. The teachers' decisions about terminology were not related directly to beliefs they held about one particular issue; rather, once again, instructional decisions in this aspect of L2 teaching were influenced by the interaction of a range of cognitions, such as beliefs about the best way to learn grammar, about the value of talk about language, and about students' knowledge of and experience of terminology. This study also provided some support for the possibility (supporting an earlier finding by Brumfit et al. 1996) that teachers' own knowledge of terminology was a factor shaping their instructional decisions. These connections between what teachers know about grammar and their approach to formal instruction were explored further in Borg (2001), where two experienced EFL teachers were compared. One teacher was generally confident in his own knowledge about grammar, and this was reflected in his willingness to conduct impromptu grammar work and to use students' questions as the springboard for unplanned class discussions of grammar. The second teacher rarely conducted grammar work and never did so unless he was prepared. A fear of not knowing the answer, triggered by a negative experience much earlier in his career, was the main influence behind this stance. These data suggested that teachers' self-perceptions of their knowledge of grammar can motivate their pedagogical decisions.

Johnston \& Goettsch (2000) examined the knowledge base underlying the grammatical explanations of 4 experienced ESL teachers in the USA. Conceptually, this study is based on categories of teacher knowledge introduced by Shulman (1987), focusing specifically on teachers' content knowledge, pedagogical content knowledge (i.e., subject-specific instructional techniques) and knowledge of learners. Defining content knowledge in this study as teachers' declarative knowledge of language, the authors examined the sources of such knowledge, finding that, in common with other studies reviewed here (Borg 1998b; Eisenstein-Ebsworth \& Schweers 1997; Farrell 1999), education and experience were the two major influences on the development of the teachers' content knowledge. The dynamic nature of the teachers' knowledge about language was also highlighted; teachers' understandings of language were constantly changing as they stored, processed, reflected on, added to, and modified what they already knew.

Johnston \& Goettsch also argue that 'the way experienced teachers give explanations of grammar 
points in class... is pedagogical content knowledge par excellence' (p. 449). Their analysis showed that grammatical rules did not feature prominently in the explanations of any of the teachers; rather, the teachers placed much more emphasis on using examples during explanations and on 'the importance of student input in facilitating their explanations' (p. 451). Another characteristic of explanations shared by all teachers was encouraging student questions and devoting significant time to student-initiated discussions. This stance was based on the general belief that such active student involvement supported the processes of understanding language.

Although they discuss content knowledge, pedagogical knowledge, and knowledge of students separately, in concluding their report Johnson \& Goettsch acknowledge that, while this discreteness is analytically convenient, "in reality, these categories are melded together in complex and indeed inextricable ways to produce multifaceted, holistic accounts of, and actions in, language teaching' (p. 461). This echoes Golombek (1998), discussed earlier, who also commented on the holistic manner in which language teachers draw on their knowledge.

\section{Summary}

This brief discussion of studies into teacher cognition in grammar teaching has highlighted different perspectives from which this issue can be approached. Teachers' knowledge of grammar can be measured through test-like instruments; teachers' beliefs can be elicited through questionnaires and interviews; and teachers' cognitions can be examined in greater complexity through analyses of actual classroom practices and discussions with teachers about these. For over 20 years the predominant source of knowledge about grammar teaching had been studies of second language acquisition (SLA); here we see evidence of a conceptual shift which, based on the realisation that SLA research had not provided definitive answers about grammar teaching, recognises teacher cognition as a key source of data in attempts to make sense of formal instruction. It is the studies where cognitions are explored with direct reference to what teachers do in classrooms and to teachers' commentaries on their work that this shift is most obvious, and continuing work of this kind is required in a greater range of language teaching contexts. Having said this, further research into language teachers' knowledge about language is also needed; for although it is clear that effective instruction depends on much more than a mastery of subject matter, our understandings of the relationships between declarative subject matter knowledge and practice in language teaching are still undeveloped.

\section{Teacher cognition in literacy instruction}

Here my focus is on studies which have examined the thinking, knowledge, and beliefs of second and foreign language teachers with respect to the teaching of reading and writing. Although there has been much research into these issues in L1 contexts (e.g., Beach 1994; Kinzer 1988; Richardson et al. 1991), my literature searches yielded only a small group of studies conducted in L2 and FL settings. Here I discuss seven such studies, five of which focus on reading instruction and two on writing.

\section{Teaching reading}

Johnson (1992b) examined the extent to which ESL teachers possess theoretical beliefs which reflect the methodological divisions of skill-based, rulebased and function-based approaches toward L2 teaching. She also analysed the extent to which teachers' theoretical beliefs were consistent with their practices. On the basis of theoretical profiling instruments completed by 30 teachers, she found that '.. the majority of these ESL teachers $(60 \%)$ possess clearly defined theoretical beliefs which consistently reflect one particular methodological approach to second language teaching' (p. 93). A function-based orientation towards reading instruction - emphasising authentic language, situational contexts, and meaningful communication - emerged here as the most commonly held. Both quantitative and qualitative analyses of the data obtained from the profiles and classroom observations showed that 'ESL teachers who possess clearly defined theoretical beliefs provide literacy instruction which is consistent with their theoretical orientation...the study supports the notion that ESL teachers teach in accordance with their theoretical beliefs and that differences in theoretical beliefs may result in differences in the nature of literacy instruction' (p. 101). The study also found a relationship between years of teaching experience and teachers' theoretical orientation, with the less experienced teachers embracing the most recent, chronologically speaking, theoretical stance (i.e., functional) and the more experienced aligning themselves with the least recent (i.e., skill-based). Once again (see the section on grammar teaching) these findings suggest that teachers' beliefs are resistant to theoretical shifts in the field and that 'the sources of ESL teachers' theoretical beliefs may stem from the methodological approaches that were prominent when they began teaching ESL' (pp. 93-94).

Collie Graden (1996) also examined the consistency between teachers' reported beliefs and their observed practices in reading instruction. Overall, her findings reflected Johnson's in that practices and beliefs were generally consistent; however, this study did highlight instances of inconsistency with regard 
Table 5 Categories of teachers' practical knowledge about teaching reading comprehension (Meijer et al. 1999, p. 64)

\begin{tabular}{ll}
\hline Category & Description \\
\hline $\begin{array}{l}\text { 1. Subject matter knowledge } \\
\text { 2. Student knowledge }\end{array}$ & $\begin{array}{c}\text { Knowledge of reading comprehension in the specific language-subject, not } \\
\text { directly related to teaching } \\
\text { Knowledge about } 16 \text { to 18-year-old students in general, not directly related } \\
\text { to reading comprehension }\end{array}$ \\
$\begin{array}{l}\text { Knowledge of the learning and understanding of 16 to 18-year-old students } \\
\text { with respect to reading comprehension }\end{array}$ \\
$\begin{array}{l}\text { 4. Knowledge of purposes } \\
\begin{array}{l}\text { 5. Knowledge of curriculum } \\
\text { Importance of, and goals for teaching reading comprehension }\end{array} \\
\text { Texts and materials used in lessons on reading comprehension } \\
\text { Design, preparation, and structure of lessons in reading comprehension }\end{array}$
\end{tabular}

to three beliefs the teachers held: (a) that students need frequent opportunities to read; (2) that the use of students' L1 should be minimised during reading instruction; and (3) that reading aloud interferes with comprehension. Practices opposed to these beliefs were observed for each of the teachers. An analysis of teachers' comments on these practices show that:

the most significant influence that led the teachers to compromise their beliefs on instructional decisions was the day-to-day necessity of planning activities for students who did not or could not perform according to the teachers' expectations. Other factors, although less often cited, were time constraints and lack of appropriate materials (p. 390).

In shaping the actual practices adopted in the classroom, the teachers' beliefs about the motivational needs of their students, then, appeared to be more powerful than the beliefs held by the teachers about effective reading instruction.

Unrelated to either of the above studies on reading instruction, Tercanlioglu (2001) examined preservice teachers' views of themselves as readers and future reading teachers. In terms of self-perception as readers, 'results revealed that respondents here are not very confident that they have the capability to read effectively' (p. 12). Moreover, this finding was stable for students at different stages of their teacher education programme (despite explicit emphasis during the programme on students' self-development as readers). With respect to self-perceptions as future teachers of reading in an FL, the study reports that the pre-service teachers themselves were not very motivated to teach reading. Although the study of self-perception is clearly an important issue in the study of teacher cognition (Borg 2001, for example, looked at self-perception in teaching grammar), the absence of any analysis of the teachers' practices in this study limits somewhat the implications of these findings.

The work in the Netherlands of Meijer, Verloop, \& Beijaard $(1999 ; 2001)$ is a major contribution to the study of teacher cognition about reading instruction to $16-18$ year olds ${ }^{17}$. Using the notion of practical knowledge as the conceptual basis of their work, and through concept mapping and interview techniques, they identified six categories of teachers' practical knowledge about reading comprehension, shown in Table 5 .

By examining patterns amongst these categories in teachers' concept maps and interview responses, they defined a typology which describes three ideal ${ }^{18}$ types of practical knowledge about teaching reading comprehension (Meijer et al. 1999). The first type is characterised by a focus on subject matter knowledge (i.e., the other categories of knowledge are defined with reference to the subject matter of reading comprehension); the second by a focus on student knowledge; and the third by a focus on knowledge of student learning and understanding. Each type is characterised by a description of the sub-categories of teacher knowledge listed in Table 5, together with a description of the background variables (e.g., formal training received) relevant to that type.

Building on this work, the same researchers conducted a quantitative study of similarities and differences in teachers' practical knowledge about reading: 69 teachers of reading comprehension to 1618 year olds completed a questionnaire in which they expressed their degree of agreement/disagreement with 167 statements. The statements in the questionnaire were based on data emerging from the earlier qualitative study and related to the categories of practical knowledge identified there. A statistical analysis of the results showed that 22 items on the questionnaire $(13.1 \%$ of the total) could be identified as shared knowledge amongst the teachers ${ }^{19}$, leading

${ }^{17}$ In the 1999 study, 4 out of 13 key participants taught mother tongue Dutch; in the 2001 study, 26 out of 69 did so. The rest of the teachers taught foreign languages.

${ }^{18}$ Ideal in the sense that rather than being descriptions of actual teachers the typologies are abstractions based on the analysis of several teachers' practical knowledge.

19 Shared knowledge does not mean that all teachers responded to an item in the same way; for example, items where $60 \%$ or 
to the conclusion that 'no large shared-knowledge base could be found in the teachers' practical knowledge' (p. 177). Subsequent analyses of the patterns in these differences in teachers' practical knowledge, however, suggested there were four clusters of teachers with relatively similar practical knowledge. The largest of these, called the segmental view on teaching reading comprehension (accounting for 25 of the 69 teachers) was characterised by teachers' concerns for the difficulties students encountered while reading and with the small elements of reading comprehension. The low appreciation for reading comprehension was the second most common cluster (20 teachers, who generally questioned the importance of reading comprehension); the large element view on reading comprehension and teaching reading comprehension by relating texts and students clusters each contained 11 teachers. These clusters pointed to the existence of some shared knowledge amongst the teachers, despite the large differences overall in their practical knowledge about reading comprehension.

Despite the value of these two studies in examining teacher cognition about teaching reading, it must be pointed out that this research did not report the study of actual practices, and the relationship between teaching behaviour and practical knowledge as elicited in these studies was not examined.

\section{Teaching writing}

Burns (1992) and Tsui (1996) have examined teachers' cognitions and practices in the context of writing instruction. Burns studied the beliefs and writing instruction practices of six teachers in beginning ESL classes in Australia. She found 'an extremely complex and interrelated network of underlying beliefs, clustering around five major areas which appeared to influence the instructional practices and approaches adopted by the teachers' (p. 59). These were (1) the nature of language as it relates to beginning language learning; (2) the relationship between written and spoken language; (3) the nature of beginning language learning and strategies relevant to language learning at this stage; (4) learner characteristics, their ability to learn, and their ability to learn English; and (5) the nature of the language classroom and the teacher's role within it. Differences in the beliefs teachers held about these issues were reflected in differences in their practices in teaching writing.

Tsui's study reports the experience over two and a half years of an EFL teacher in Hong

more of the teachers provided the same answer were considered shared knowledge; so too items where $90 \%$ or more of the teachers answered '(dis)agree' and '(dis)agree emphatically'; a very small variance across responses on an item was also taken to be indicative of shared knowledge.
Kong who, dissatisfied with a product approach to wring instruction, introduced process writing into her classroom. Despite the positive reactions of the teacher and the students, process writing was problematic because students were writing fewer compositions than other classes (process writing was more time- consuming) and students were making more grammatical mistakes than before (this concerned the teacher because accuracy was important in the public examinations students would be sitting). Wider support for the process approach was also not provided by the teacher's head of department. Consequently, the teacher reverted to a product approach, although in time she eventually implemented a modified version of process writing which was not as time-consuming as the one she had first tried to implement. This study illustrates changes in the teacher's cognitions and practices over time, and further highlights the manner in which institutional and curricular factors can constrain teachers' capacity to implement practices they feel are desirable.

\section{Summary}

Given their centrality in language teaching, it is perhaps surprising that reading and writing instruction have not been awarded more attention in L2 and FL teacher cognition research ${ }^{20}$. Nonetheless, the small group of studies reviewed here substantively, conceptually, and methodologically diverse - provide a basis for further work of this kind. Teachers' voices are somewhat lacking in the studies of reading discussed here (only in one case were teachers given the chance to talk about their work), and this is clearly an issue future studies of reading might address. The Netherlands studies can be linked to the efforts of Breen et al. (2001) to seek shared patterns of cognition across groups of teachers, though, as already noted, the practical knowledge studies tell us nothing about what happens in classrooms. Further analyses of reading instruction grounded in the description of real practices, then, are also required. The studies of writing are very different, though both ground their discussion of teacher cognition in detailed analysis of classroom practices. In addition, Tsui's case study illustrates the value of longitudinal research in tracing and making sense of changes in teachers' cognitions and practices over time. Much more research on L2 and FL teachers' practices and cognitions in teaching writing is required.

\footnotetext{
${ }^{20}$ A reviewer of this paper has however pointed out the existence of research in the US, Canada, and Australia on teachers' professional learning in the teaching of $\mathrm{L} 2$ writing which may be
} relevant to this review. 


\section{Conclusion}

In this section I will make some concluding observations on the review of literature I have presented here, examining in particular the current state of language teacher cognition research and directions for continued enquiry.

1. The study of language teacher cognition is, beyond doubt, a well-established domain of enquiry. We are now, to return to Freeman's (2002) characterisation, entering our decade of consolidation in which the groundwork laid in the 1990s can be extended.

2. One goal for this consolidation is the development of programmatic research agendas conceived within an overall unifying framework for language teacher cognition research. Figure 1, for example, reflected my efforts to conceptualise as a unified field mainstream research on teacher cognition, and this might provide a starting point for the development by researchers in the field of a more specific framework for language teacher cognition research. Such a framework is necessary for several reasons; it militates against the accumulation of isolated studies conducted without sufficient awareness of how these relate to existing work; it reminds researchers of key dimensions in the study of language teacher cognition (e.g., prior learning, professional education, context); and it highlights key themes and relationships and promotes more focused attention to these.

3. Another goal for this domain of enquiry must be more focused research on different curricular aspects of language teaching. Grammar teaching and literacy instruction in FL and L2 contexts have both been awarded some attention (though this, especially for literacy, is by no means sufficient). I am also aware of one study in relation to $\mathrm{L} 2$ teachers' use of technology. Other major areas, such as the teaching of speaking and listening, remain unstudied from a teacher cognition perspective. Similarly, the surge in interest in teaching languages to young learners has not been matched by studies of cognitions and practices in this area (though Breen at al. 2001 \& Rea-Dickins \& Rixon 1999 show some awareness of the need for such work). In terms of specific curricular focuses, then, there is still much work to be done as far as language teacher cognition is concerned. Studying language teaching in this manner can also lead to findings which are of unique relevance to our field; much of the work on language teacher decision-making, for example, simply confirms what mainstream educational research had already shown.

4. Although this body of work reflects key issues studied in mainstream educational research (e.g., interactive decision-making), it does also highlight additional themes which have much potential for expanding our understanding of this field: three in particular are (a) relationships between cognitive and behavioural change, (b) changes in the content and structure of teacher cognition, and (c) mapping the processes of change in teachers' cognitions and practices. This last theme in particular highlights the need for more longitudinal studies of language teacher cognition, both in teacher education contexts as well as in the work of practising teachers.

5. Language teacher cognition research has understandably been heavily influenced by conceptualisations of teaching developed in other academic fields (e.g., Shulman's notion of pedagogical content knowledge). This raises a key ontological issue regarding the extent to which language teachers, because of their subject matter, are similar or different to teachers of other subjects. There is little explicit discussion of this issue in the work I have reviewed here, but the overall implication of this work is that understandings of teacher cognition and practice developed in subjects such as mathematics and science can be usefully applied in the study of language teaching. This is clearly, however, an issue which needs to be addressed more explicitly in continuing work in this field. Freeman (2002: 6), for example, has already suggested that 'when applied to language as subject matter, PCK [pedagogical content knowledge] becomes a messy and unworkable concept'. Andrews (2001) has also proposed ways in which general concepts such as subject matter knowledge might be related to those more specific to language teaching, such as teachers' language awareness. Further exploration of such issues is required.

6. Although I have not discussed methodological issues in detail here, the work reviewed reflects a wide range of research methods. These are largely qualitative, though there is also evidence of the contribution that quantitative work can make to this domain of inquiry. One key question which emerges is Can language teacher cognition be usefully studied without reference to what happens in classrooms? Personally I am sceptical, though it is clear that where large numbers of teachers are being studied and/or ideal typologies are being developed, analyses solely of teachers' reported cognitions can provide a useful basis for further inquiry. Ultimately, though, we are interested in understanding teachers' professional actions, not what or how they think in isolation of what they do.

7. The question of what counts as evidence of teacher cognition is also one for continued consideration. Here we have seen diverse answers to this question: responses to questionnaires, teachers' retrospective commentaries on their instructional decisions, repertory grid data, comments elicited through video-based stimulated recall, data from theoretical profiling instruments, various forms of interview 
data, and observed or reported classroom practices: all of these have been cited, individually or in combinations, as evidence of the unobservable psychological context of language teaching. Further discussion of the merits of these different forms of data and of ways of combining them in studying language teacher cognition is another way forward as this domain of inquiry continues to develop.

8. Another central issue to emerge here is the role of context. Greater understandings of the contextual factors - e.g., institutional, social, instructional, physical - which shape what language teachers do are central to deeper insights into relationships between cognition and practice. The study of cognition and practice without an awareness of the contexts in which these occur will inevitably provide partial, if not flawed, characterisations of teachers and teaching.

9. One further observation is that the range of contexts studied to date is, in global terms, perhaps not representative of language teaching settings. Much research has been conducted with native speaker teachers working with small groups of motivated adult learners studying in universities or private institutions. In contrast, we have minimal insight into state school settings (primary and secondary) where languages are taught by nonnative teachers to large classes of learners who, particularly in the case of English, may not be studying the language voluntarily. Investigations of such settings, then, are another priority.

10. Finally, an important issue I have not had space to deal with here is the implications of all this research for the professional preparation and continuing development of language teachers. Teacher educators need to be (and there is much evidence that they are) considering the meaning of this body of research for the principles underlying the design of their programmes; at a more detailed level, reflection is also required on how actual data (e.g., case studies of teachers' practices and cognitions) from this research might be made available to trainees and teachers as the basis of teacher education activities (for discussions of this issue and examples see Borg 1998a; in press; Merseth 1996).

\section{References}

Almarza, G. (1996). Student foreign language teachers' growth. In D. Freeman \& J. C. Richards (eds.), Teacher Learning in Language Teaching (pp. 50-78). Cambridge: Cambridge University Press.

Andrews, S. (1994). The Grammatical Knowledge/ Awareness of Native-Speaker EFL Teachers: What the Trainers Say. In M. Bygate, A. Tonkyn \& E. Williams (eds.), Grammar and the Language Teacher (pp. 69-89). London: Prentice Hall International.
Andrews, S. (1997). Metalinguistic knowledge and teacher explanation. Language Awareness, 6 (2/3), 147-61.

AnDREws, S. (1999a). 'All these like little name things': a comparative study of language teachers' explicit knowledge of grammar and grammatical terminology. Language Awareness, 8 (3/4), 143-59.

ANDrews, S. (1999b). Why do L2 teachers need to 'know about language'? Teacher metalinguistic awareness and input for learning. Language and Education, 13 (3), $161-77$.

ANDREws, S. (2001). The language awareness of the L2 teacher: Its impact upon pedagogical practice. Language Awareness, 10 (2 \& 3), 75-90.

Bailey, K. M. (1996). The best laid plans: teachers' inclass decisions to depart from their lesson plans. In K. M. Bailey \& D. Nunan (eds.), Voices From the Language Classroom (pp. 15-40). Cambridge: Cambridge University Press.

Bailey, K. M., B. Bergthold, B. Braunstein, N. Jagodzinski Fleischman, M. P. Holbrook, J. Tuman, X. Waissbluth \& L. J. Zambo(1996). The language learners' autobiography: examining the "apprenticeship of observation". In D. Freeman \& J. C. Richards (Eds.), Teacher Learning in Language Teaching (pp. 11-29). New York: Cambridge University Press.

Bartels, N. (1999). How teachers use their knowledge of English. In H. Trappes-Lomax \& I. McGrath (eds.), Theory in Language Teacher Education (pp. 46-56). London: Prentice Hall.

BEACH, S. A. (1994). Teacher's theories and classroom practice: beliefs, knowledge, or context? Reading Psychology, 15 (3), 189-96.

Berry, R. (1997). Teachers' awareness of learners' knowledge: The case of metalinguistic terminology. Language Awareness, $6(2 / 3), 136-46$.

BORG, S. (1997). Unifying concepts in the study of teachers' cognitive structures. Unpublished manuscript.

Borg, S. (1998a). Data-based teacher development. ELT Journal, 52 (4), 273-81.

BORG, S. (1998b). Talking about grammar in the foreign language classroom. Language Awareness, 7 (4), 159-75.

BorG, S. (1998c). Teachers' pedagogical systems and grammar teaching: A qualitative study. TESOL Quarterly, 32 (1), 9-38.

Borg, S. (1999a). Studying teacher cognition in second language grammar teaching. System, 27 (1), 19-31.

BORG, S. (1999b). Teacher cognition in second language grammar teaching. Unpublished PhD thesis, University of Exeter, Exeter, UK.

Borg, S. (1999c). Teachers' theories in grammar teaching. ELT Journal, 53 (3), 157-67.

BorG, S. (1999d). The use of grammatical terminology in the second language classroom: A qualitative study of teachers' practices and cognitions. Applied Linguistics, 20 (1), 95-126.

Borg, S. (2001). Self-perception and practice in teaching grammar. ELT Journal, 55 (1), 21-9.

BORG, S. (in press). Knowing and doing: Teaching grammar in in-service training. In D. Liu \& P. Masters (eds.), Grammar Teaching in Teacher Education. Alexandra, VA: TESOL.

Borko, H. \& C. Livingston (1989). Cognition and improvisation: Differences in mathematics instruction by expert and novice teachers. American Educational Research Journal, 26 (4), 473-98.

BreEn, M. P. (1991). Understanding the language teacher. In R. Phillipson, E. Kellerman, L. Selinker, M. Sharwood Smith \& M. Swain (eds.), Foreign/Second Language Pedagogy Research (pp. 213-33). Clevedon, UK: Multilingual Matters. 
Breen, M. P., B. Hird, M. Milton, R. Oliver \& A. Thwaite (2001). Making sense of language teaching: teachers' principles and classroom practices. Applied Linguistics, 22 (4), 470-501.

Brookhart, S. M. \& D. J. Freeman (1992). Characteristics of entering teacher candidates. Review of Educational Research, 62 (1), 37-60.

Brown, J. \& J. McGannon (1998). What do I know about language learning? The story of the beginning teacher. From http://www.cltr.uq.edu.au/alaa/proceed/ bro-mcgan.html. Accessed 3 July (2002).

Brumfit, C., R. Mitchell \& J. Hooper (1996). Grammar, language and classroom practice. In M. Hughes (ed.), Teaching and Learning in Changing Times (pp. 70-87). Oxford: Blackwell.

Burgess, J. \& S. Etherington (2002). Focus on grammatical form: explicit or implicit? System, 30, 433-58.

Burns, A. (1992). Teacher beliefs and their influence on classroom practice. Prospect, 7 (3), 56-66.

Burns, A. (1996). Starting all over again: From teaching adults to teaching beginners. In D. Freeman \& J. C. Richards (eds.), Teacher Learning in Language Teaching (pp. 154-77). Cambridge: Cambridge University Press.

Cabaroglu, N. \& J. Roberts (2000). Development in student teachers' pre-existing beliefs during a 1-Year PGCE programme. System, 28 (3), 387-402.

Calderhead, J. (1996). Teachers: beliefs and knowledge. In D. C. Berliner \& R. C. Calfee (eds.), Handbook of Educational Psychology (pp. 709-25). New York: Macmillan.

Carter, K. (1990). Teachers' knowledge and learning to teach. In W. R. Houston (ed.), Handbook of Research on Teacher Education (pp. 291-310). New York: Macmillan.

Cathcart, R. \& J. E. W. B. Olsen (1976). Teachers' and students' preferences for the correction of classroom conversation errors. In J. Fanselow \& R. H. Crymes (eds.), On TESOL '76. Washington, DC: TESOL.

Chandler, P., W. P. Robinson \& P. Noyes (1988). The level of linguistic knowledge and awareness among students training to be primary teachers. Language and Education, 2 (3), 161-73.

Clandinin, J. D. \& M. F. Connelly (1987). Teachers' personal knowledge: What counts as personal in studies of the personal. Journal of Curriculum Studies, 19 (6), $487-500$.

Clark, C. M. \& P. L. Peterson (1986). Teachers' thought processes. In M. C. Wittrock (Ed.), Handbook of Research on Teaching. (3rd edn., pp. 255-96). New York: Macmillan.

Collie Graden, E. (1996). How language teachers' beliefs about reading are mediated by their beliefs about students. Foreign Language Annals, 29 (3), 387-95.

Crookes, G. \& L. Arakaki (1999). Teaching idea sources and work conditions in an ESL program. TESOL Journal, 8 (1), 15-19.

Cumming, A. (1989). Student teachers' conceptions of curriculum: Towards an understanding of language teacher development. TESL Canada Journal, 7 (1), 33-51.

Dunkin, M. J. (1995). Synthesising research in education: a case study of getting it wrong. The Australian Educational Researcher, 22 (1), 17-33.

Dunkin, M. J. (1996). Types of errors in synthesizing research in education. Review of Educational Research, 66 (2), 87-97.

Eisenhart, M. A., J. L. Shrum, J. R. Harding \& A. M. Cuthbert (1988). Teacher beliefs: definitions, findings and directions. Educational Policy, 2 (1), 51-70.

Eisenstein-Ebsworth, M. \& C. W. Schweers (1997). What researchers say and practitioners do: Perspectives on conscious grammar instruction in the ESL classroom. Applied Language Learning, 8, 237-60.
Elbaz, F. (1981). The teacher's "practical knowledge": A report of a case study. Curriculum Inquiry, 11, 43-71.

Faerch, C. (1985). Meta talk in FL classroom discourse. Studies in Second Language Acquisition., 7 (2), 184-99.

Farrell, T. S. C. (1999). The reflective assignment: unlocking pre-service teachers' beliefs on grammar teaching. RELC Journal, 30 (2), 1-17.

Feiman-Nemser, S. \& R. E. Floden (1986). The cultures of teaching. In M. C. Wittrock (Ed.), Handbook of Research on Teaching (3rd ed., pp. 505-26). New York: Macmillan.

Fenstermacher, G. D. (1994). The knower and the known: The nature of knowledge in research on teaching. Review of Research in Education, 20, 1-54.

Foss, D. H. \& R. C. Kleinsasser (1996). Preservice elementary teachers' views of pedagogical and mathematical content knowledge. Teaching and Teacher Education, 12 (4), 429-42.

Freeman, D. (1993). Renaming experience/reconstructing practice: developing new understandings of teaching. Teaching and Teacher Education, 9 (5/6), 485-97.

Freeman, D. (1996). The "unstudied problem": research on teacher learning in language teaching. In D. Freeman \& J. C. Richards (Eds.), Teacher Learning in Language Teaching (pp. 351-78). Cambridge: Cambridge University Press.

FreEman, D. (2002). The hidden side of the work: Teacher knowledge and learning to teach. Language Teaching, 35 $(1-13)$.

GAtBonton, E. (1999). Investigating experienced ESL teachers' pedagogical knowledge. The Modern Language Journal, 83 (1), 35-50.

GolombeK, P. R. (1998). A study of language teachers' personal practical knowledge. TESOL Quarterly, 32 (3), 447-64.

Grossman, P. M., S. M. Wilson \& L. S. Shulman (1989). Teachers of substance: subject matter knowledge for teaching. In M. C. Reynolds (Ed.), Knowledge Base for the Beginning Teacher (pp. 23-36). Oxford: Pergamon.

Holt Reynolds, D. (1992). Personal history-based beliefs as relevant prior knowledge in course work. American Educational Research Journal, 29 (2), 325-49.

Johnson, K. E. (1992a). Learning to teach: instructional actions and decisions of preservice ESL teachers. TESOL Quarterly, 26 (3), 507-35.

Johnson, K. E. (1992b). The relationship between teachers' beliefs and practices during literacy instruction for nonnative speakers of English. Journal of Reading Behavior, 24 (1), 83-108.

Johnson, K. E. (1994). The emerging beliefs and instructional practices of preservice English as a second language teachers. Teaching and Teacher Education, 10 (4), $439-52$.

Johnson, K. E. (1996). The vision versus the reality: The tensions of the TESOL practicum. In D. Freeman \& J. C. Richards (eds.), Teacher Learning in Language Teaching (pp. 30-49). Cambridge: Cambridge University Press.

Johnston, B. \& K. Goettsch (2000). In search of the knowledge base of language teaching: Explanations by experienced teachers. The Canadian Modern Language Review, 56 (3), 437-68.

KagAN, D. (1990). Ways of evaluating teacher cognition: inferences concerning the Goldilocks principle. Review of Educational Research, 60 (3), 419-69.

Kagan, D. (1992). Professional growth among preservice and beginning teachers. Review of Educational Research, 62, 129-69.

Kelly, G. A. (1955). The Psychology of Personal Constructs: A Theory of Personality (Vols. 1 \& 2). New York: W. W. Norton. 
Kettle, B. \& N. Sellars (1996). The development of student teachers' practical theory of teaching. Teaching and Teacher Education, 12 (1), 1-24.

Kinzer, C. K. (1988). Instructional frameworks and instructional choices: Comparisons between preservice and inservice teachers. Journal of Reading Behaviour, 20, 357-77.

LAM, Y. (2000). Technophilia vs. technophobia: A preliminary look at why second-language teachers do or do not use technology in their classrooms. Canadian Modern Language Review, 56 (3), 390-420.

Lightbown, P. M. \& N. Spada (1993). How Languages are Learned. Oxford: Oxford University Press.

LorTiE, D. (1975). Schoolteacher: A Sociological Study. Chicago: University of Chicago Press.

MacDonald, M., R. Badger \& G. White (2001). Changing values: what use are theories of language learning and teaching? Teaching and Teacher Education, 17 (8), 949-63.

McCargar, D. F. (1993). Teacher and student role expectations: cross-cultural differences and implications. Modern Language Journal, 77, 192-207.

Meijer, P. C., N. Verloop \& D. BeijaArd (1999). Exploring language teachers' practical knowledge about teaching reading comprehension. Teaching and Teacher Education, 15, 59-84.

Meijer, P. C., N. Verloop \& D. BeijaArd (2001). Similarities and differences in teachers' practical knowledge about teaching reading comprehension. Journal of Educational Research, 94 (3), 171-84.

Merseth, K. K. (1996). Cases and case methods in teacher education. In J. Sikula (ed.), Handbook of Research on Teacher Education (pp. 722-44). New York: MacMillan.

Mitchell, R. \& J. Hooper (1992). Teachers' views of language knowledge. In C. James \& P. Garrett (eds.), Language Awareness in the Classroom (pp. 40-50). London: Longman.

Mitchell, R., C. Brumfit \& J. Hooper (1994a). Knowledge about language: policy, rationales and practices. Research Papers in Education, 9 (2), 183-205.

Mitchell, R., C. Brumfit \& J. Hooper (1994b). Perceptions of language and language learning in English and foreign language classrooms. In M. Hughes (ed.), Perceptions of Teaching and Learning (pp. 53-65). Clevedon: Multilingual Matters.

MoK, W. E. (1994). Reflecting on reflections: A case study of experienced and inexperienced ESL teachers. System, 22 (1), 93-111.

Nespor, J. (1987). The role of beliefs in the practice of teaching. Journal of Curriculum Studies, 19 (4), 317-28.

Nisbett, R. E. \& L. Ross (1980). Human Inference: Strategies and Shortcoming of Social Judgment. Englewood Cliff, NJ: Prentice Hall.

Numrich, C. (1996). On becoming a language teacher: Insights from diary studies. TESOL Quarterly, 30 (1), 131-53.

NunAn, D. (1992). The teacher as decision-maker. In J. Flowerdew, M. Brock \& S. Hsia (eds.), Perspectives on Second Language Teacher Education (pp. 135-65). Hong Kong: City Polytechnic.

Orton, R. E. (1996). How can teacher beliefs about student learning be justified? Curriculum Inquiry, 26 (2), 133-46.

Pajares, M. F. (1992). Teachers' beliefs and educational research: cleaning up a messy construct. Review of Educational Research, 62 (3), 307-32.

Peacock, M. (2001). Pre-service ESL teachers' beliefs about second language learning: a longitudinal study. System, 29, $177-95$.
Rea-Dickins, P. \& S. Rixon (1999). Assessment of young learners' English: reasons and means. In S. Rixon (ed.), Young Learners of English: Some Research Perspectives (pp. 89-101). Harlow: Lognman/The British Council.

RichardS, J. C. (1996). Teachers' maxims in language teaching. TESOL Quarterly, 30 (2), 281-96.

Richards, J. C. (1998a). Teacher beliefs and decision making. In J. C. Richards (ed.), Beyond Training (pp. 65-85). Cambridge: CUP.

RichaRds, J. C. (1998b). What's the use of lesson plans? In J. C. Richards (ed.), Beyond Training (pp. 103-21). Cambridge: CUP.

Richards, J. C. \& M. Pennington (1998). The first year of teaching. In J. C. Richards (ed.), Beyond Training (pp. 173-90). Cambridge: CUP.

Richards, J. C., B. Ho \& K. Giblin (1996). Learning how to teach in the RSA Cert. In D. Freeman \& J. C. Richards (eds.), Teacher Learning in Language Teaching (pp. 242-59). Cambridge: Cambridge University Press.

Richards, J. C., B. Li \& A. TANG (1998). Exploring pedagogical reasoning skills. In J. C. Richards (ed.), Beyond Training (pp. 86-102). Cambridge: CUP.

Richards, J. C., P. Tung \& P. NG (1992). The culture of the English language teacher: a Hong Kong example. RELC Journal, 23 (1), 81-102.

Richardson, V. (1996). The role of attitudes and beliefs in learning to teach. In J. Sikula (ed.), Handbook of Research on Teacher Education (2nd edn., pp. 102-19). New York: Macmillan.

Richardson, V., P. Anders, D. Tidwell \& C. Lloyd (1991). The relationship between teachers' beliefs and practices in reading comprehension instruction. American Educational Research Journal, 28 (3), 559-86.

Schulz, R. A. (1996). Focus on form in the foreign language classroom: Students' and teachers' views on error correction and the role of grammar. Foreign Language Annals, 29 (3), 343-64.

Schulz, R. A. (2001). Cultural differences in student and teacher perceptions concerning the role of grammar teaching and corrective feedback: USA-Colombia. Modern Language Journal, 85 (2), 244-58.

Sendan, F. \& J. Roberts (1998). Orhan: a case study in the development of a student teachers' personal theories. Teachers and Teaching: Theory and Practice, 4, 229-44.

Shavelson, R. J. \& P. Stern (1981). Research on teachers' pedagogical thoughts, judgements and behaviours. Review of Educational Research, 51 (4), 455-98.

Shulman, L. S. (1987). Knowledge and teaching: Foundations of the new reform. Harvard Educational Review, 57 (1), $1-22$.

SMith, D. B. (1996). Teacher decision making in the adult ESL classroom. In D. Freeman \& J. C. Richards (eds.), Teacher Learning in Language Teaching (pp. 197-216). Cambridge: Cambridge University Press.

Spada, N. \& M. Massey (1992). The role of prior pedagogical knowledge in determining the practice of novice ESL teachers. In J. Flowerdew, M. Brock \& S. Hsia (eds.), Perspectives on Second Language Teacher Education (pp. 23-37). Hong Kong: City Polytechnic.

Tabachnick, B. R. \& K. M. Zeichner (1986). Teacher beliefs and classroom behaviours: some teacher responses to inconsistency. In M. Ben-Peretz, R. Bromme \& R. Halkes (eds.), Advances of Research on Teacher Thinking (pp. 84-96). Lisse, Netherlands: Swets and Zeitlinger.

Tercanlioglu, L. (2001). Pre-service teachers as readers and future teachers of EFL reading. TESL-EJ, $\mathbf{5}$ (3). From http://www.zait.uni-bremen.de/wwwgast/tesl ej/ej19/a2.html. Accessed 3 July 2002

Tsui, A. B. M. (1996). Learning how to teach ESL writing. In D. Freeman \& J. C. Richards (eds.), Teacher Learning in 
Language Teaching (pp. 97-119). Cambridge: Cambridge University Press.

Ulichny, P. (1996). What's in a methodology? In D. Freeman \& J. C. Richards (eds.), Teacher Learning in Language Teaching (pp. 178-96). Cambridge: Cambridge University Press.

Verloop, N., J. Van Driel \& P. C. Meijer (2001). Teacher knowledge and the knowledge base of teaching. International Journal of Educational Research, 35 (5), 441-61.

Weinstein, C. S. (1990). Prospective elementary teachers' beliefs about teaching: Implications for teacher education. Teaching and Teacher Education, 6 (3), 279-90.
Williamson, J. \& F. Hardman (1995). Time for refilling the bath? A study of primary student-teachers' grammatical knowledge. Language and Education, 9 (2), 117-34.

Wilson, S. M., R. E. Floden \& J. Ferrini-Mundy (2002). Teacher preparation research: an insider's view from the outside. Journal of Teacher Education, 53 (3), 190-204.

Woods, D. (1991). Teachers' interpretations of second language teaching curricula. RELC Journal, 22, 1-19.

Woods, D. (1996). Teacher Cognition in Language Teaching. Cambridge: Cambridge University Press.

Wray, D. (1993). Student-teachers' knowledge and beliefs about language. In N. Bennett \& C. Carré (eds.), Learning to Teach. London: Routledge. 